

\section{Sumário}

CrôNiCAS DA ATUALIDADE do DiREITo INTERnACIONAL ..................................................... 2 Sarah Dayanna Lacerda Martins Lima, Carina Costa de Oliveira e Erika Braga

CrôniCas do Direito InternaCional dos InVESTIMENTOS ..............................................12 Nitish Monebhurrun

Por que voltar a Kelsen, o jurista do século XX ? 16 Inocêncio Mártires Coelho

O Princípio da Efetividade como conteúdo da norma fundamental (GrundNorm) DE KELSEN

Carlos Alberto Simões de Tomaz e Renata Mantovani de Lima

A JURIDIFICAÇÃo DE CONFLITOS POLÍTICOS NO DIREITO INTERNACIONAL PÚBLICO CONTEMPORÂ-

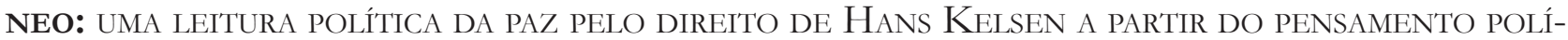
TICO De Claude Lefort

Arthur Roberto Capella Giannattasio

O SINCRETISMO TEÓRICO NA APROPRIAÇÃO DAS TEORIAS MONISTA E DUALISTA E SUA QUESTIONÁVEL UTILIDADE COMO CRITÉRIO PARA A CLASSIFICAÇÃO DO MODELO BRASILEIRO DE INCORPORA-

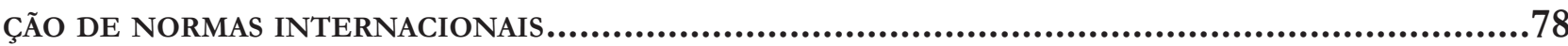
Breno Baía Magalhães

Direito Global em Pedaços: Fragmentação, Regimes e Pluralismo .98 Salem Hikmat Nasser

Por uma TeOria JURÍdica da INTEGRaÇão REgIONAL: A INTER-RELAÇÃO DiREITO INTERNO, DiREITO INTERNACIONAL PÚBLICO E DIREITO DA INTEGRAÇÃO Jamile Bergamaschine Mata Diz e Augusto Jaeger Júnior

A teOria DA INTERCONSTITUCIONALIDADE: UMA ANÁlISE COM BASE NA AMÉRICA LATINA...........160 Daniela Menengoti Ribeiro e Malu Romancini 
O DIÁLOGO HERMENÊUTICO E A PERGUNTA ADEQUADA À APLICAÇÃo DOS TRATADOS INTERNACIONAIS DE DIREITOS HUMANOS NO BRASIL: CAMINHOS PARA O PROCESSO DE INTERNACIONALIZAÇÃO

DA CONSTITUIÇÃO...................................................................................... 176

Rafael Fonseca Ferreira e Celine Barreto Anadon

O DIREITO COMPARADO NO STF: INTERNACIONALIZAÇÃO DA JURISDIÇÃO CONSTITUCIONAL BRASILEIRA

Carlos Bastide Horbach

THE PHILOSOPHY OF INTERNATIONAL LAW IN CONTEMPORARY SCHOLARSHIP: OVERCOMING NE-

GLIGENCE THROUGH THE GLOBAL EXPANSION OF HUMAN RIGHTS

Fabrício Bertini Pasquot Polido, Lucas Costa dos Anjos e Vinícius Machado Calixto

OpORTUNIDADES E DESAFIOS DAS TWAIL NO CONTEXTO LATINO-AMERICANO A PARTIR DE PERSPECTIVAS DOS POVOS INDÍGENAS AO DIREITO INTERNACIONAL

Fernanda Cristina de Oliveira Franco

Por Que uma ANÁlise ECONÔMICA Do DIREITO INTERNACIONAL PÚBLICO? DESAFIOS E PERSPECTIVAS DO MÉTODO NO BRASII

Gustavo Ferreira Ribeiro e Jose Guilherme Moreno Caiado

ANÁliSE ECONÔMICA do DIREITO INTERNACIONAL .263 Michele Alessandra Hastreiter e Luís Alexandre Carta Winter

RACIONALIDADE ECONÔMICA E OS ACORDOS BILATERAIS DE INVESTIMENTO 284 Michele Alessandra Hastreiter e Luís Alexandre Carta Winter

LOOKING FOR A BRICS PERSPECTIVE ON INTERNATIONAL LAW .304 Gabriel Webber Ziero

A INFLUÊNCIA DO DIREITO DESPORTIVO TRANSNACIONAL NO ORDENAMENTO JURÍDICO BRASILEIRO: DA REPRODUÇÃO DE NORMAS À APLICAÇÃO DIRETA PELA JURISDIÇÃO ESTATAL.......................3324 Tiago Silveira de Faria

CONVENCIONALIZAÇÃo DO DIREITO CIVIL: A APLICAÇÃo DOS TRATADOS E CONVENÇÕES INTERNACIONAIS NO ÂMBITO DAS RELAÇÕES PRIVADAS . 
NATIONAL JUdGES AND COURTS AS INSTITUTIONS FOR GLOBAL ECONOMIC GOVERNANCE 356

Juízes e tribunais nacionais como instituições para a governança global 356 Camilla Capucio

Is Trade Governance Changing? 371 Alberto do Amaral Júnior

OS FUNDOS ABUTRES: MEROS PARTICIPANTES DO CENÁRIO INTERNACIONAL OU SUJEITOS PERANTE O DIREITO INTERNACIONAL? 384

Guilherme Berger Schmitt

SHAREHOLDER AGREEMENTS IN PUBLICLY TRADED COMPANIES: A COMPARISON BETWEEN THE

U.S. AND BRAZIL. 402 Helena Masullo

REgulaÇÃo DO INVESTIMENTO ESTRANGEIRO DIRETO NO BRASIL: DA RESISTÊNCIA AOS TRATADOS BILATERAIS DE INVESTIMENTO À EMERGÊNCIA DE UM NOVO MODELO REGULATÓRIO 421 Fabio Morosini e Ely Caetano Xavier Júnior

DA QUALIFICAÇÃo JURÍDiCA dAS Distintas FORMAS DE PRESTAÇão TECNOLÓGICA: BREVE ANÁLISE DO MARCO REGULATÓRIO INTERNACIONAL

Daniel Amin Ferraz

REDEFINING TERRORISM: THE DANGER OF MISUNDERSTANDING THE MODERN WORLD'S GRAVEST THREAT

Jennifer Breedon

As EXECUÇões SELETIVAS E A RESPONSABILIZAÇÃo DE AGENTES TERRORISTAS 485 Alexandre Guerreiro

INTERNATIONAL CRIMINALS AND THEIR VIRTUAL CURRENCIES: THE NEED FOR AN INTERNATIONAL EFFORT IN REGULATING VIRTUAL CURRENCIES AND COMBATING CYBER CRIME Joy Marie Virga

Criminalidad transnacional organizada en el Ámbito del MERCOSUR: ¿Hacia un Derecho Penal Regional?. .528 Nicolás Santiago Cordini e Mariano Javier Hoet 
RUMO À INTERNACIONALIZAÇÃo DA PROTEÇÃO PENAL DO MEIO AMBIENTE: DOS ECOCRIMES AO ECOCÍDIO

Kathia Martin-Chenut, Laurent Neyret e Camila Perruso

Engaging the U.N. Guiding Principles on Business and Human Rights: the inter-AMERICAN COMMISSION ON HUMAN RIGHTS \& THE EXTRACTIVE SECTOR 571 Cindy S. Woods

O DIREITO HUMANO À COMUNICAÇÃo PRÉVIA E PORMENORIZADA DAS ACUSAÇÕES NOS PROCESSOS administrativos: O desprezo do Superior Tribunal de Justiça ao Pacto de San José da Costa Rica e À Corte Interamericana de Direitos Humanos .590

Daniel Wunder Hachem e Eloi Pethechust

A responsabilidade internacional do Brasil em FaCe do CONTRole de ConVENCionaliDADE EM SEDE DE DIREITOS HUMANOS: CONFLITO DE INTERPRETAÇÃO ENTRE A JURISDIÇÃO DA Corte Interamericana de Direitos Humanos e o Supremo Tribunal Federal quanto a LEI DE ANISTIA 612

Carla Ribeiro Volpini Silva e Bruno Wanderley Junior

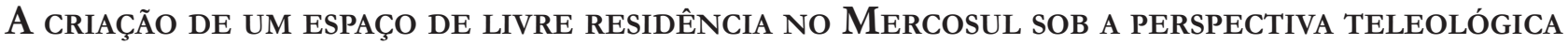
DA INTEGRAÇÃo REGIONAL: ASPECTOS NORMATIVOS E SOCIAIS DOS ACORDOS DE RESIDÊNCIA ....... 631

Aline Beltrame de Moura

A funcionalização como tendênCia evolutiva do Direito Internacional e sua conTRIBUIÇÃO AO REGIME LEGAL DO BANCO DE DADOS DE IDENTIFICAÇÃO DE PERFIL GENÉTICO NO BRASIL

Antonio Henrique Graciano Suxberger

O DIREITO INTERNACIONAL E A PROTEÇÃO DOS DIREITOS DE CRIANÇAS E DE ADOLESCENTES EM CONFLITO COM A LEI EM MOÇAMBIQUE

Bernardo Fernando Sicoche

ObTenÇão de PRovas no EXTERIOR: PARA ALÉM dA LEX FORI E LEX DiLigENTIAE. .685 André De Carvalho Ramos 
A Slight Revenge and a Growing Hope for Mauritius and the Chagossians: The UNClos Arbitral Tribunal's Award of 18 March 2015 on Chagos Marine Protected Area (Mauritius v. United Kingdom)

Géraldine Giraudeau

ANÁLISE DA RESPONSABILIDADE INTERNACIONAL DA UCRÂNIA POR VIOLAÇÃo DOS DIREITOS HUmanos na QUeda do voo da Malaysia Airlines (MH17). .728

Daniela Copetti Cravo

NatureZa JURÍdica do DESENVOLVIMENTO SUSTENTÁVEL No DIREITO INTERNACIONAL ........739 Pedro Ivo Diniz

A INFLUÊNCIA Da SOFT LAW NA FORMaÇão do DiREITo AMBIENTAL .767 Leonardo da Rocha de Souza e Margareth Anne Leister

As COMPLICADAS INTER-RELAÇÕES ENTRE OS SISTEMAS INTERNOS E INTERNACIONAIS DE PROTEÇãO DO DIREITO AO MEIO AMBIENTE SADIO. 785 José Adércio Leite Sampaio e Beatriz Souza Costa 


\title{
Looking for a BRICS perspective on international law*
}

\section{À procura de uma perspectiva dos BRICS sobre direito internacional}

Gabriel Webber Ziero*

\begin{abstract}
The aim of this paper is to analyze whether there is a BRICS perspective on international law and what would be its main features. In the first part, the investigation inquires, based on Nietzsche's theory of perspectivism, what a perspective is and whether the BRICS fulfils these theoretical thresholds necessary to possess a perspective on international law. After answering positively to this question, the areas of international peace and security, human rights as well as international economic law are scrutinized in order to verify how the BRICS perceives international law. The first two fields were chosen given the fact that they are the fundaments of the international legal system established after 1945, while the latter is related to the area where the BRICS has been focusing its attention since its creation. In a third moment, based on the findings of the previous sections, the structural fundaments of the group's perspective on international law are identified. Finally, it is possible to conclude that the BRICS perspective on international law is based and shaped by the continuous interactions between the fields of international relations and international law present in the consensus-building process in international organizations as well as by the concept of state sovereignty. These findings allow filling the gap in legal research on the BRICS and better understanding its approach to international law.
\end{abstract}

Keywords: BRICS. Public international law. Perspective. International peace and security. Human rights. International economic law.

\section{Resumo}

O objetivo deste artigo é analisar se existe uma perspectiva dos BRICS quanto ao direito internacional e quais seriam as suas principais características. Na primeira parte, com base na teoria do perspectivismo de Nietzsche, busca-se definir o que é uma perspectiva, bem como se os BRICS preenchem os critérios teóricos necessários para ter uma perspectiva acerca do direito internacional. Após responder positivamente a essa questão, as áreas de paz e segurança internacional, direitos humanos, bem de direito econômico internacional são analisadas a fim de verificar como os BRICS lidam com direito internacional. Os dois primeiros campos foram escolhidos tendo em vista o fato de que eles são os fundamentos do sistema jurídico internacional estabelecido após 1945, enquanto o terceiro está relacionado com a área 
onde os BRICS têm focado a sua atenção desde a sua criação. Em um terceiro momento, com base nos resultados das seções anteriores, os fundamentos estruturais da perspectiva do grupo acerca do direito internacional são identificados. Finalmente, é possível concluir que a perspectiva dos BRICS quanto ao direito internacional se baseia e é moldada pelas interações contínuas entre os domínios das relações internacionais e do direito internacional presente no processo de construção de consenso no seio das organizações internacionais, bem como pelo conceito de soberania do Estado. Tais conclusões permitem preencher a lacuna na pesquisa jurídica sobre os BRICS e ajudam a compreender melhor como os BRICS lidam com o direito internacional.

Palavras-chave: BRICS. Direito internacional público. Perspectiva. Paz e segurança internacional. Direitos humanos. Direito internacional econômico.

\section{INTRODUCTION}

The financial market often designates investment scenarios using acronyms, such as CIVETS (Colombia, Indonesia, Vietnam, Egypt, Turkey and South Africa) and VISTA (Vietnam, Indonesia, South Africa, Turkey and Argentina). This was also the case when in the beginning of the second millennium an investment forecast of Jim O'Neill created the expression BRIC, which was nothing more than a short form to address Brazil, Russia, India and China as a group of countries in an economic prognosis. ${ }^{1}$ Yet, differently than the other acronyms, the BRIC countries promoted their development as a group and established their own diplomatic channel in order to coordinate their actions in the most different fields of the international arena. ${ }^{2}$

The integration of the group in the international scenario started in a sideline meeting of Foreign Ministers during the $61^{\text {st }}$ United Nations General Assembly (UNGA) in 2006 and has been concretized in 2009 at the first BRIC Summit of Heads of States in Yekaterinburg (Russia). Moreover, the most significant moments for the establishment

1 O'NEILL, Jim. Building better global economic BRICs. New York: Goldman, Sach, Nov. 2001. (Global Economics Paper, n. 66). Available on: <http://www.goldmansachs.com/our-thinking/archive/ archive-pdfs/build-better-brics.pdf>. Access: Oct. 16, 2015.

2 REIS, Maria E. F. BRICS: genesis and evolution. In: PIMENTEL, José Vicente de Sá (Ed.). Brazil, BRICS and the international agenda. Brasília: FUNAG, 2013. p. 47-71 p. 51. of the group as an actor in the international arena were the integration of South Africa in 2011 and the subsequent creation of the New Development Bank (NDB) as well as the BRICS Contingent Reserve Agreement (CRA) in 2014. Therefore, fifteen years after they were first named as a group by O'Neill and after South Africa joined the group, Brazil, Russia, India, China and South Africa, or simply the BRICS, represent more than forty percent of the world's population and their added Gross Domestic Product (GDP) corresponds to more than one quarter of the world's economy. ${ }^{3}$ The group thus became an important player of international relations with the capacity to shape processes and outcomes in the international arena, which are commonly inserted within the international legal framework.

However, although the BRICS has become a trend topic in the last years in what regards academic publications, ${ }^{4}$ few are the analyses of the group departing from and within the field of public international law. This is why this paper wants to investigate how the BRICS, as a group and prominent player in international relations, perceives international law. An inquiry about such a BRICS perspective is relevant not only due to the lack of research related to this topic, but also because the levels of institutionalization and cooperation within or through the group are increasing each year. Moreover, it is via the domain of public international law, i.e. "the aggregate of the legal norms governing international relations" ${ }^{5}$, that these actions are and will be expressed.

In order to conduct such investigation, this paper analyzes primary sources drafted by the five countries as a group, such as declarations, statements and plans of action issued by the BRICS Summits of Heads of States, and is divided into three parts. The first one analyzes by means of Nietzsche's philosophy on perspectivism whether the BRICS, as a group, can have its own perspective on international law. The next section aims

3 RUSSIA. Presidency. Official Website of Russia's Presidency in BRICS: BRICS in numbers. 2015. Available on: < http://en.brics2015.ru/infographics/20150301/24260.html>. Access: Oct. 16, 2015.

4 See, for example: REWIZORSKI, Marek (Ed.). The European Union and the BRICS: complex relations in the Era of Global Governance. New York: Springer, 2015. FERDINAND, Peter. Rising powers at the UN: an analysis of the voting behaviour of BRICS in the General Assembly. Third World Quarterly, v. 35, n. 3, p. 376-391, May 2014. KIRTON, John. BRICS evolving institutional identity: explaining the brics summit's solid strengthening success. International Organizations Research Journal, v. 10, n. 2, p. 9-31, Jun. 2015.

5 GUGGENHEIM, Paul. Traité de droit international. Genève: Libraire Georg, 1967. p. 1. 
to explore such BRICS perspective on international law addressing three areas of the discipline, which are: the two core goals of the post-World War II international order, i.e. international peace and security and human rights, as well as international economic law, as this is the area on which the BRICS has been concentrating its efforts since its creation. Finally, the third part puts forward the framework, i.e. the basic ideas that underlie the identified BRICS perspective on international law.

\section{INTERNATIONAL LAW AND ITS PERSPECTIVES: IS THERE A BRICS PERSPECTIVE?}

International law regulates a broad range of issues, from the deep seabed until the outer space, as well as a myriad of actors, such as states, international organization or non-state armed groups. ${ }^{6}$ As a consequence of these innumerous interactions with, within and through the framework of international law, it is possible to indentify several theoretical approaches towards such regulatory regime. For instance, theories approaching international law through the lenses of fragmentation, ${ }^{7}$ feminism ${ }^{8}$ and TWAIL, give an idea that international law can be accessed from uncountable angles, i.e. perspectives. Nevertheless, in front of such scenario a question comes-up: What counts as a perspective?

In order to answer the above mentioned question as well as to verify if there is a BRICS perspective on international law, this section briefly presents Nietzsche's theory of perspectivism in order to understand what a perspective is and how it can be identified. After that, based on the identified elements, upon which a perspective is built, this section scrutinizes whether it can be affirmed that there is a BRICS perspective on international law.

\subsection{The question of perspectivism}

6 SHAW, Malcolm. International law. Cambridge: Cambridge University, 2008. p. 2.

7 KOSKENNIEMI, Martti; LEINO, Päivi. Fragmentation of international law? postmodern anxieties. Leiden Journal of International Law, v. 15, n. 3, p. 553-579, Sept. 2002.

8 KUOVO, Sari; PEARSON, Zoe (Ed.). Feminist perspectives on contemporary international law: between resistance and compliance? Oxford: Hart, 2011.

9 MUTUA, Makau. What it TWAIL? In: ANNUAL MEETING AMERICAN SOCIETY OF INTERNATIONAL LAW, 94., Washington, 2000. Proceedings... Washington: ASIL, Apr. 2000. p. 31-39.
Debates related to a theory of perspective can be traced back to Nietzsche's philosophy where the question of perspectivism (Perspektivismus) is related to the interpretation that a person or group gives to the world that surrounds it. ${ }^{10}$ This idea departs from the understanding that the world does not possesses "any features that are in principle prior to and independent of interpretation". ${ }^{11}$ Moreover, during such hermeneutic process, the subject tries to compel others to accept its worldview as a norm. ${ }^{12}$ In the field of international law, especially during the legalization process, ${ }^{13}$ it is possible to witness the presence of different perspectives on a certain topic or the discipline as a whole, which are put forward by different actors involved in it. For example, during the negotiation process for the creation of the International Criminal Court groups of states as well as movements from civil society presented their views trying to influence the drafting process in order to have their perspectives on international criminal law and justice enshrined in the final treaty. ${ }^{14}$

From the idea of perspectivism, it is possible to identify three decisive elements, which are necessary to be present in order for a specific perspective on something to exist. They are: the participants (persons or group); their interpretation and the cogent power that they give to their worldview. Hence, in order to address the question whether a BRICS perspective on international law exists, this paper shall analyze the group through these three lenses.

\subsection{BRICS: The participant}

Nietzsche's theory of perspectivism is structured on as well as departs from an individual or group, which

10 NIETZSCHE, Friedrich. The will to power. New York: Vintage Books, 1967. p. 267.

11 NEHAMAS, Alexander. Nietzsche: life as literature. Cambridge: Harvard University, 1985. p. 45.

12 NIETZSCHE, Friedrich. The will to power. New York: Vintage Books, 1967. p. 267.

13 This paper adopts the expression "international legalization process" put forward by Abbot and Sindal as it has a broader meaning than the expression "international law-making process". It embodies not only aspects related to the creational process of a certain rule, but also includes normativity considerations, such as the degree of bindingness and precision of the rule. See: ABBOT, Kenneth; SINDAL, Duncan. Hard and soft law in international governance. International Organization, v. 53, n. 3, p. 421-453, Jun. 2000.

14 KIRSCH, Philippe; HOLMES, John T. The Rome Conference on an International Criminal Court: The Negotiating Process. The American Journal of International Law, v. 93, n. 1, p. 2-12, Jan. 1999. 
perceives the world that surrounds it. ${ }^{15}$ It has to be noted that the term "group" implies the presence of a shared interpretation of a subject as well as a certain degree of coordination among its members. Consequently, in order to verify whether there is a BRICS perspective, it is necessary to analyze how the BRICS, as a group, addresses international law and not the individual perspective of its members. Therefore, this section aims at providing a concise analysis of the BRICS members perception of the forum trying to identify common areas and not to investigate the degree of differences among the participants or the causes of such.

In what regards the required degree of coordination, it can be observed that the group has been structuring its relations via an informal legalization strategy, ${ }^{16}$ meaning that the BRICS sets aside some formalities, which are characteristic for the traditional ways in which international cooperation is shaped. For example, instead of establishing an international organization via an international agreement under international law with the presence of at least one organ with an independent will from its members ${ }^{17}$ in order to enhance its strategies regarding cooperation and coordination of policies, the BRICS are in the process of creating a virtual secretariat $^{18}$ responsible for a joint BRICS website designated "to strengthen comprehensive cooperation between the Member States" ${ }^{\prime 1}$. Moreover, the group has an extensive practice in the use of memoranda of understanding, i.e. documents that do not create rights and obligations under international law among its signatories, for example between governmental agencies, state-owned banks and ministries traditionally not involved in the classical international legalization process. ${ }^{20}$ Such lack of legally

15 NIETZSCHE, Friedrich. The will to power. New York: Vintage Books, 1967. p. 267.

16 PAUWELYN, Joost. Informal international lawmaking: framing the concept and research questions. In: PAUWELYN, Joost; WESSEL, Ramses; WOUTERS, Jan (Ed.). Informal international lawmaking. Oxford: Oxford University, 2012. p. 13-34.

17 SCHERMERS, Henry G.; BLOKKER, Niels M. International institutional law. Leiden: M. Nijhoff, 2011. p. 37.

18 UNIVERSITY OF TORONTO. VII BRICS summit: $2015 \mathrm{Ufa}$ Declaration. Ufa, July 9, 2015. Available on: <http://www.brics.utoronto.ca/docs/150709-ufa-declaration_en.html>. Access: Oct. 17, 2015. (Hereinafter: Ufa Declaration), point 77.

19 UNIVERSITY OF TORONTO. Memorandum of understanding on the creation of the joint BRICS Website. Ufa, July 9, 2015. Available on: <http://www.brics.utoronto.ca/docs/150709-website-en. html>. Access: Oct. 17, 2015. Preamble.

20 A list of all memorandums of understanding among the BRICS is UNIVERSITY OF TORONTO. BRICS Information Centre. Available on: <http://www.brics.utoronto.ca/>. Access: Oct. 17, 2015. binding sources, in particular a founding treaty, which in the area of international law is perceived as one of the requirements for the characterization of an international organization, does not impair the possibility to consider the BRICS as a group in the terms of Nietzsche's theory. Differently than the strict requirements put forward by international legal scholarship in order to determine if a group of countries is an international organization, Nietzsche's theory of perspectivism does not require a high level of formalism. Nevertheless, it is important to mention that since 2014 the role played by legally binding documents governed by international law has been increasing with the BRICS agreements creating the NDB as well as the BRICS Contingent Reserve in 2014 and the agreement on cooperation in the field of culture in $2015 .^{21}$

In what regards the shared interpretation, it needs to be observed that the BRICS participants do not always fully agree or support each other's positions. ${ }^{22}$ This was for example the case of the Bali Agreement (2013) ${ }^{23}$ related to the Doha Round at the World Trade Organization (WTO), where India blocked the negotiations for a certain period and almost undermined the trade deal, which was supported by the other BRICS countries. ${ }^{24}$ Nevertheless, although differences exist, the will to act together, as a group, addressing particular issues provides the BRICS with an opportunity to create and strengthen the coordination between its members, as it is required by Nietzsche's theory. As an example of this, it is possible to mention the BRICS countries common efforts via the forum to reform the global economic/ financial architecture. ${ }^{25}$ Furthermore, the group's inte-

21 UNIVERSITY OF TORONTO. Agreement between the governments of the BRICS states on cooperation in the field of culture. Ufassia, July 9, 2015. Available on: <http://www.brics.utoronto.ca/ docs/150709-culture-agreement-en.html>. Access: Oct. 17, 2015

22 COOPER, Andrew; FAROOQ, Assif. Testing the club dynamics of the BRICS: the new development bank from conception to establishment. International Organizations Research Journal, v. 10, n. 2, p. 32-44, Jun. 2015. p. 3.

23 BRAGA, Erika. Um panorama sobre as negociações do Pacote de Bali e os seus desdobramentos no âmbito da OMC. Brazilian Journal of International Law. v. 12, n. 2, p. 16-20, dez. 2014.

24 WTO MINISTERIAL CONFERENCE, 9., 2013, Bali, 2013. Proceedings... Valencia: Instituto de Tecnología y Alimentos Agroquímica, 2014. Available at: <https://www.wto.org/english/ thewto_e/minist_e/mc9_e/balipackage_e.htm>. Access: Oct. 21, 2015.

25 COOPER, Andrew; FAROOQ, Assif. Testing the club dynamics of the BRICS: the new development bank from conception to establishment. International Organizations Research Journal, v. 10, n. 2, p. 32-44, Jun. 2015. 
gration is based on the self-identification of its members as emergent economies, ${ }^{26}$ which also corresponds to the image, which other players have of them. ${ }^{27} \mathrm{Mo}-$ reover, the BRICS bases itself on a non-confrontational approach, ${ }^{28}$ where consensus does not only play a relevant role during the decision-making process, but also at the selection of the themes to be addressed. Consequently, the group understands itself as "a major platform for dialogue and cooperation" 29 that aims to become a "full-fledged mechanism of current and long-term coordination on a wide range of key issues of the world economy and politics" 30 .

The theory of perspectivism requires the presence of shared interpretations and a degree of coordination among the members of a group and does not look at the formalities that are usually essential in the area of international institutional law. Also, it does not require a complete harmony in opinions or the absence of differences among the participants of a group. Therefore, it is possible to affirm that the BRICS satisfies the theoretical requirements to be called a group according to Nietzsche's theory, in the sense that it "acts as the

26 For example: UNIVERSITY OF TORONTO. Joint statement of the BRIC countries' leaders. Yekaterinburg, June 16, 2009. Available on: $<$ http://www.brics.utoronto.ca/docs/090616-leaders.html>. Access: Oct. 17, 2015. (Hereinafter: Yekaterinburg Statement), point 15; UNIVERSITY OF TORONTO. Sanya Declaration. Sanya, Apr. 14, 2011. Available on: <http://www.brics.utoronto.ca/docs/110414leaders.html>. Access: Oct. 17, 2015. (Hereinafter: Sanya Declaration), points 5, 6, 7, 15, 16; UNIVERSITY OF TORONTO. The 6th BRICS summit: Fortaleza Declaration. Fortaleza, July 15, 2014. Available on: <http://www.brics.utoronto.ca/docs/140715-leaders. html>. Access: Oct. 17, 2015. (Hereinafter: Fortaleza Declaration), points 3, 5, 8, 11.

27 See, for example: KEUKELEIRE, Stephan et al. The EU Foreign Policy towards the BRICS and other emerging powers: objectives and strategies. Brussels: European Parliament, Oct. 2009. Available on: $<$ https:/ / www.google.com.br/url?sa $=\mathrm{t} \& \mathrm{rct}=\mathrm{j} \& \mathrm{q}=\&$ esrc $=\mathrm{s} \&$ sourc $\mathrm{e}=$ web\&cd $=1 \& \mathrm{cad}=$ rja\&uact $=8 \& v e d=0$ hUKEwi $4 \mathrm{mcvBtuDKAh}$ XIgZAKHfztAEIQFggfMAA\&url=http $\% 3 \mathrm{~A} \% 2 \mathrm{~F} \% 2 \mathrm{Fwww}$.europarl.europa.eu $\% 2$ Fcommittees $\% 2$ Fen $\% 2$ Fstudiesdownload.html $\%$ 3FlanguageDocument $\% 3$ DEN $\% 26$ file $\% 3 D$ 49151\&usg=AFQjCN G5J6ipEQ5iXvDSwbAi01VZhesbPQ\&sig2=NWyUUYcBlZeAT EH_ed07PA>. Access: Oct. 16, 2015.

28 UNIVERSITY OF TORONTO. Sanya Declaration. Sanya, Apr. 14, 2011. Available on: <http://www.brics.utoronto.ca/ docs/110414-leaders.html>. Access: Oct. 17, 2015. point 6.

29 UNIVERSITY OF TORONTO. Sanya Declaration. Sanya, Apr. 14, 2011. Available on: <http://www.brics.utoronto.ca/ docs/110414-leaders.html>. Access: Oct. 17, 2015. point 6.

30 UNIVERSITY OF TORONTO. BRICS and Africa: partnership for development, integration and industrialization, eThekwini Declaration. Durban, Mar. 27, 2013. Available on: <http://www. brics.utoronto.ca/docs/130327-statement.html>. Access: Oct. 17, 2015. (Hereinafter: eThekwini Declaration). point 21. hub that irons out differences and illustrates how [...] diversity does not entail divergence or conflict"31. As a consequence, in order to conclude whether the BRICS has a perspective on international law, it is necessary to verify if the group tries to compel other actors to follow its interpretations regarding the world.

\subsection{BRICS: Interpretation and cogent power}

Besides the necessity of an agent, which can be an individual or a group, the theory of perspectivism requires that this actor interprets the surrounding world and tries to compel others to accept this interpretation as a blueprint to build their understandings. ${ }^{32}$ In the case of the BRICS, it is possible to perceive that the group aims at complementing global governance ${ }^{33}$ by developing as well as proposing solutions to the current challenges faced by the structures of the international system, which in its view are endowed with a lack of legitimacy and representation. ${ }^{34}$ Moreover, according to the group's interpretation, the current multi-polar international scenario has to "based on international law, equality, mutual respect, cooperation, coordinated action and collective decision-making of all States" ${ }^{\prime 35}$.

The BRICS strategy to gain support for its inter-

31 TSINGOU, Eleni. Club governance and the making of global financial rules. Review of International Political Economy, v. 22, n. 2, p. 225-256, Mar. 2015. p. 232. See also: KIRTON, John. BRICS evolving institutional identity: explaining the BRICS summit's solid strengthening success. International Organizations Research Journal, v. 10, n. 2, p. 9-31, Jun. 2015. p. 13.

32 NIETZSCHE, Friedrich. The will to power. New York: Vintage Books, 1967. p. 267.

33 REIS, Maria E. F. BRICS: genesis and evolution. In: PIMENTEL, José Vicente de Sá (Ed.). Brazil, BRICS and the international agenda. Brasília: FUNAG, 2013. p. 47-71. p. 56.

34 UNIVERSITY OF TORONTO. Joint statement of the BRIC countries' leaders. Yekaterinburg, June 16, 2009. Available on: < http:// www.brics.utoronto.ca/docs/090616-leaders.html>. Access: Oct. 17, 2015. point 3; UNIVERSITY OF TORONTO. Sanya Declaration. Sanya, Apr. 14, 2011. Available on: <http://www.brics.utoronto.ca/ docs/110414-leaders.html>. Access: Oct. 17, 2015. points 8, 15; UNIVERSITY OF TORONTO. Fourth BRICS summit: Delhi Declaration. New Delhi, Mar. 29, 2012. Available on: <http://www.brics. utoronto.ca/docs/120329-delhi-declaration.html>. Access: Oct. 17, 2015. (Hereinafter: Delhi Declaration), point 25; UNIVERSITY OF TORONTO. The 6th BRICS summit: Fortaleza Declaration. Fortaleza, July 15, 2014. Available on: <http://www.brics.utoronto.ca/ docs/140715-leaders.html>. Access: Oct. 17, 2015. point 5.

35 UNIVERSITY OF TORONTO. 2nd BRIC summit of heads of state and government: joint statement. Brasília, Apr. 15, 2010. Available on: <http://www.brics.utoronto.ca/docs/100415-leaders.html>. Access: Oct. 17, 2015. (Hereinafter: Brasília Statement), point 2. 
pretation of the international scenario by other players, and therefore to make its interpretation valid, has been to focus its attention on a particular area of global governance where the group plays an important role, namely the financial/economical architecture. The BRICS approach towards this agenda can be found in its critics to the way that international financial institutions dealt with the 2008 economic crisis and with its spillover effects. According to the group, the Group of Eight (G-8) and the Bretton Woods institutions, especially the International Monetary Fund (IMF) and the World Bank (WB), are not representative enough and incapable to propose solutions to the crisis given the lack of representation of emergent economies and developing countries in their structures. ${ }^{36}$

Consequently, the BRICS advocated for the placement of the debate related to the economic crisis in the Group of Twenty (G-20), which it sees as a more representative forum, ${ }^{37}$ as well as called for and supports the reform processes of the IMF and the WB. ${ }^{38}$ Nevertheless, the BRICS went a step further in the process of compelling other actors to follow its interpretations by giving a follow-up to its open critics to the already established world financial structure. This was when the group, in 2014, signed the constitutive treaty of the New Development Bank (NDB) in order to aid all

36 UNIVERSITY OF TORONTO. Sanya Declaration. Sanya, Apr. 14, 2011. Available on: <http://www.brics.utoronto.ca/ docs/110414-leaders.html>. Access: Oct. 17, 2015. point 15.

37 UNIVERSITY OF TORONTO. Fourth BRICS summit: Delhi Declaration. New Delhi, Mar. 29, 2012. Available on: <http://www. brics.utoronto.ca/docs/120329-delhi-declaration.html>. Access: Oct. 17, 2015. point 7 .

38 UNIVERSITY OF TORONTO. Joint statement of the BRIC countries' leaders. Yekaterinburg, June 16, 2009. Available on: <http:// www.brics.utoronto.ca/docs/090616-leaders.html>. Access: Oct. 17, 2015. point 3; UNIVERSITY OF TORONTO. 2nd BRIC summit of heads of state and government: joint statement. Brasília, Apr. 15, 2010. Available on: <http://www.brics.utoronto.ca/docs/100415-leaders. html>. Access: Oct. 17, 2015. point 10; Sanya Declaration, point 15; UNIVERSITY OF TORONTO. Fourth BRICS summit: Delhi Declaration. New Delhi, Mar. 29, 2012. Available on: < http://www. brics.utoronto.ca/docs/120329-delhi-declaration.html>. Access: Oct. 17, 2015. point 8; UNIVERSITY OF TORONTO. BRICS and Africa: partnership for development, integration and industrialization, eThekwini Declaration. Durban, Mar. 27, 2013. Available on: <http://www.brics.utoronto.ca/docs/130327-statement.html>. Access: Oct. 17, 2015. point 13; UNIVERSITY OF TORONTO. The 6th BRICS summit: Fortaleza Declaration. Fortaleza, July 15, 2014. Available on: <http://www.brics.utoronto.ca/docs/140715leaders.html>. Access: Oct. 17, 2015. point 18; UNIVERSITY OF TORONTO. VII BRICS summit: 2015 Ufa Declaration. Ufa, July 9, 2015. Available on: <http://www.brics.utoronto.ca/docs/150709ufa-declaration_en.html>. Access: Oct. 17, 2015. point 12. emergent countries that "continue to face significant financing constraints to address infrastructures gaps and sustainable development needs" 39 . Consequently, this institution can be seen as an attempt from the BRICS to gain support as well as to compel other countries to adopt the group's understandings, i.e. the critical perspective on the existing international financial/economic architecture.

Building on Nietzsche's philosophy of perspectivism as well as on the examples brought forward by this section, it can be affirmed that there is a BRICS perspective on international law. It could be identified in a first moment that the group has a particular approach towards the international arena, which can be differentiated from the ones adopted by its members. Moreover, it could be noticed that the BRICS expresses its interpretations not only via discursive means, such as diplomatic declarations, but also through actions, for example by creating the NDB, aiming at compelling and gaining support from other players. Nevertheless, it is not possible to have a clear image and understanding of how the BRICS perspective on international law looks like just by assessing the elements that form the idea of perspectivism. In order to discover this, it is necessary to dive into BRICS practice and to relate it to international law.

\section{INTERNATIONAL LAW THROUGH THE BRICS LENSES}

At a first glance it is difficult to dissociate the BRICS perspective on international relations from its perspective on international law. Nevertheless, aiming at verifying how the BRICS perceives international law, it is necessary to engage in a deeper analysis of the BRICS interpretation of the international system, especially by assessing how the group perceives the fundaments of today's international (legal) order.

In 1945, the United Nations Charter launched the basis for the international system of the post-World War II focusing on two main areas: maintenance of international peace and security and human rights. ${ }^{40}$ Since

39 UNIVERSITY OF TORONTO. The 6th BRICS summit: Fortaleza Declaration. Fortaleza, July 15, 2014. Available on: <http:// www.brics.utoronto.ca/docs/140715-leaders.html>. Access: Oct. 17, 2015. point 11 .

40 See for example Article 1 of the UN Charter. 
then these ideas have been influencing how different actors interpret international law. As a consequence, it seems relevant to verify how the BRICS addresses these topics in order to have a better idea of how it perceives international law. This is done in the first two subsections of this part. Moreover, as mentioned above, the BRICS has been concentrating its actions on a particular area of global governance, which is the economic/ financial architecture, consequently, in a third moment, it is investigated how the group approaches the area of international economic law, a very important pillar of the globalized world order.

\subsection{International peace and security}

The maintenance of international peace and security is the main objective of the United Nations (Article 1(1) of the UN Charter) and the Security Council is the organ with the primary, but not exclusive, ${ }^{41}$ responsibility to ensure that this goal is achieved (Article 24(1) of the UN Charter). According to the BRICS, the issue of international peace and security has to be assessed in accordance with its indivisible nature ${ }^{42}$ in the sense that the area of international peace and security does not only involve questions directly related to the threat or use of force by a state, but also a broader range of factors that might affect the sovereignty of a country, such as economic interference, terrorism etc. ${ }^{43}$ This approach can also be seen since the beginning of the 1990's in the practice of the UN Security Council and General Assembly that have expanded their interpretations of

41 In the Wall Opinion the International Court of Justice has stated based on Article 12 of the UN Charter that the General Assembly can deal in parallel with issues related to the question of international peace and security. See: Legal Consequences of the Construction of a Wall in the Occupied Palestinian Territory, Advisory Opinion, I. C. J. Reports 2004, p. 136, para. 27.

42 UNIVERSITY OF TORONTO. The 6th BRICS summit: Fortaleza Declaration. Fortaleza, July 15, 2014. Available on: <http:// www.brics.utoronto.ca/docs/140715-leaders.html>. Access: Oct. 17, 2015. point 27; UNIVERSITY OF TORONTO. VII BRICS summit: 2015 Ufa Declaration. Ufa, July 9, 2015. Available on: <http:// www.brics.utoronto.ca/docs/150709-ufa-declaration_en.html>. Access: Oct. 17, 2015. point 8 .

43 UNIVERSITY OF TORONTO. The 6th BRICS summit: Fortaleza Declaration. Fortaleza, July 15, 2014. Available on: <http:// www.brics.utoronto.ca/docs/140715-leaders.html>. Access: Oct. 17, 2015. point 27. See also: SALMON, Trevor. The nature of peace and security. In: MATHER, Alexander; BRYDEN, John (Ed.). Encyclopedia of life support systems, regional sustainable development. Paris: UNESCO, 2009. p. 259-276. p. 259. the term "threat to peace" present in the UN Charter. ${ }^{44}$

Moreover, according to the BRICS, the achievement of a sustainable peace ${ }^{45}$ is only possible if it is based on a "comprehensive, concerted and determined approach, based on mutual trust, mutual benefit, equity and cooperation" 46 , which has to rely on "generally recognized principles and rules of international law"47. For instance, the group structures its normative benchmark regarding the area of international peace and security on the UN Charter as well as on the UN Declaration on Principles of International Law concerning Friendly Relations and Cooperation among States in accordance with the Charter of the United Nations. ${ }^{48}$ The BRICS approach towards this fundament of the current international legal order bases on generally recognized principles and rules of international law and can be clearly noticed in the way the group has been dealing with the topics of terrorism ${ }^{49}$ and conflicts, such as in Syria, Afghanistan and Ukraine.

In the case of terrorism, the BRICS puts forward that the UN plays a key-role by acting as a coordinator of the efforts related to the fight against terrorism ${ }^{50}$ always in ac-

44 TALMON, Stefan. The security council as world legislature. The American Journal of International Law, v. 99, n. 1, p. 175-193, Jan. 2005. p. 181.

45 UNIVERSITY OF TORONTO. VII BRICS summit: 2015 Ufa Declaration. Ufa, July 9, 2015. Available on: <http://www.brics.utoronto.ca/docs/150709-ufa-declaration_en.html>. Access: Oct. 17, 2015. points 6-9.

46 UNIVERSITY OF TORONTO. VII BRICS summit: 2015 Ufa Declaration. Ufa, July 9, 2015. Available on: <http://www.brics.utoronto.ca/docs/150709-ufa-declaration_en.html>. Access: Oct. 17, 2015. point 9 .

47 UNIVERSITY OF TORONTO. VII BRICS summit: 2015 Ufa Declaration. Ufa, July 9, 2015. Available on: <http://www.brics.utoronto.ca/docs/150709-ufa-declaration_en.html>. Access: Oct. 17, 2015. point 6 .

48 UNIVERSITY OF TORONTO. BRICS and Africa: partnership for development, integration and industrialization, eThekwini Declaration. Durban, Mar. 27, 2013. Available on: <http://www. brics.utoronto.ca/docs/130327-statement.html>. Access: Oct. 17, 2015. point 21; UNIVERSITY OF TORONTO. The 6th BRICS summit: Fortaleza Declaration. Fortaleza, July 15, 2014. Available on: $<$ http://www.brics.utoronto.ca/docs/140715-leaders.html>. Access: Oct. 17, 2015. point 27; UNIVERSITY OF TORONTO. VII BRICS summit: 2015 Ufa Declaration. Ufa, July 9, 2015. Available on: <http://www.brics.utoronto.ca/docs/150709-ufa-declaration_ en.html>. Access: Oct. 17, 2015. point 6.

49 Since the first BRICS Summit in 2009, the topic of terrorism has always been addressed by the group.

50 UNIVERSITY OF TORONTO. Sanya Declaration. Sanya, Apr. 14, 2011. Available on: <http://www.brics.utoronto.ca/ docs/110414-leaders.html>. Access: Oct. 17, 2015. point 11; UNIVERSITY OF TORONTO. The 6th BRICS summit: Fortaleza Dec- 
cordance with principles and norms of international law, ${ }^{51}$ "including the UN Charter, international refugee and humanitarian law, human rights and fundamental freedoms" $"$. The same approach can be found when the group addresses conflict situations. The centrality of the UN has been affirmed since the first time the group has addressed a conflict, which was the situation in Libya..$^{53}$ Also the necessity to act within the limits set by international law, for example, respect for states sovereignty and territorial integrity ${ }^{54}$ are constantly mentioned by the group when addressing similar situations. Moreover, the BRICS has been highlighting the importance of national dialogue ${ }^{55}$ and "compliance with the UN Charter and universally recognized human rights and fundamental freedoms ${ }^{" 56}$ as necessary steps for the

laration. Fortaleza, July 15, 2014. Available on: <http://www.brics. utoronto.ca/docs/140715-leaders.html>. Access: Oct. 17, 2015. point 48 .

51 UNIVERSITY OF TORONTO. 2nd BRIC summit of heads of state and government: joint statement. Brasília, Apr. 15, 2010. Available on: <http://www.brics.utoronto.ca/docs/100415-leaders.html>. Access: Oct. 17, 2015. point 23; UNIVERSITY OF TORONTO. Fourth BRICS summit: Delhi Declaration. New Delhi, Mar. 29, 2012. Available on: <http://www.brics.utoronto.ca/docs/120329-delhideclaration.html>. Access: Oct. 17, 2015. point 25.

52 UNIVERSITY OF TORONTO. VII BRICS summit: 2015 Ufa Declaration. Ufa, July 9, 2015. Available on: <http://www.brics.utoronto.ca/docs/150709-ufa-declaration_en.html>. Access: Oct. 17, 2015. point 27 .

53 UNIVERSITY OF TORONTO. 2nd BRIC summit of heads of state and government: joint statement. Brasília, Apr. 15, 2010. Available on: <http://www.brics.utoronto.ca/docs/100415-leaders.html >. Access: Oct. 17, 2015. point 10.

54 E.g. in what regards the conflict in Syria: UNIVERSITY OF TORONTO. Fourth BRICS summit: Delhi Declaration. New Delhi, Mar. 29, 2012. Available on: <http://www.brics.utoronto.ca/ docs/120329-delhi-declaration.html>. Access: Oct. 17, 2015. point 21; UNIVERSITY OF TORONTO. BRICS and Africa: partnership for development, integration and industrialization, eThekwini Declaration. Durban, Mar. 27, 2013. Available on: <http://www. brics.utoronto.ca/docs/130327-statement.html>. Access: Oct. 17, 2015. point 26; UNIVERSITY OF TORONTO. The 6th BRICS summit: Fortaleza Declaration. Fortaleza, July 15, 2014. Available on: $<$ http://www.brics.utoronto.ca/docs/140715-leaders.html>. Access: Oct. 17, 2015. point 37.

55 UNIVERSITY OF TORONTO. Fourth BRICS summit: Delhi Declaration. New Delhi, Mar. 29, 2012. Available on: <http://www. brics.utoronto.ca/docs/120329-delhi-declaration.html>. Access: Oct. 17, 2015. point 21; UNIVERSITY OF TORONTO. BRICS and Africa: partnership for development, integration and industrialization, e'Thekwini Declaration. Durban, Mar. 27, 2013. Available on: <http://www.brics.utoronto.ca/docs/130327-statement.html>. Access: Oct. 17, 2015. points 26, 29, 30; Fortaleza Declaration, points 32, 37, 43, 44.

56 UNIVERSITY OF TORONTO. The 6th BRICS summit: Fortaleza Declaration. Fortaleza, July 15, 2014. Available on: <http:// www.brics.utoronto.ca/docs/140715-leaders.html>. Access: Oct. 17, 2015. point 44 . achievement of a sustainable peace in conflict situations. Furthermore, it is important to highlight that this approach is also applied to cases such as the Ukraine ${ }^{57}$ and Syria, ${ }^{58}$ which are highly sensitive for the BRICS members, especially Russia that is actively involved in both scenarios. This fact that the group follows its line also in issues that involve one of its members and not only in other cases such as Afghanistan ${ }^{59}$ shows the integrity of such approach.

Consequently, in the area of international peace and security it is possible to highlight that the BRICS has a broad understanding of what might be considered a threat to international peace and states' sovereignty, which embodies not only the use of force, but also other forms of coercion. Furthermore, the group puts forward the necessity to assess situations in this context based on generally recognized principles of international law.

\subsection{Human rights}

The respect for human rights is the other pillar of the post-World War II international system, which was laid-down by the UN Charter and afterwards confir-

57 UNIVERSITY OF TORONTO. The 6th BRICS summit: Fortaleza Declaration. Fortaleza, July 15, 2014. Available on: <http:// www.brics.utoronto.ca/docs/140715-leaders.html>. Access: Oct. 17, 2015. point 44; UNIVERSITY OF TORONTO. VII BRICS summit: 2015 Ufa Declaration. Ufa, July 9, 2015. Available on: <http:// www.brics.utoronto.ca/docs/150709-ufa-declaration_en.html>. Access: Oct. 17, 2015. point 43.

58 UNIVERSITY OF TORONTO. Fourth BRICS summit: Delhi Declaration. New Delhi, Mar. 29, 2012. Available on: < http://www. brics.utoronto.ca/docs/120329-delhi-declaration.html>. Access: Oct. 17, 2015. point 21; UNIVERSITY OF TORONTO. BRICS and Africa: partnership for development, integration and industrialization, eThekwini Declaration. Durban, Mar. 27, 2013. Available on: <http://www.brics.utoronto.ca/docs/130327-statement.html>. Access: Oct. 17, 2015. point 26; UNIVERSITY OF TORONTO. VII BRICS summit: 2015 Ufa Declaration. Ufa, July 9, 2015. Available on: <http://www.brics.utoronto.ca/docs/150709-ufa-declaration_en.html>. Access: Oct. 17, 2015.point 36.

59 UNIVERSITY OF TORONTO. Fourth BRICS summit: Delhi Declaration. New Delhi, Mar. 29, 2012. Available on: < http://www. brics.utoronto.ca/docs/120329-delhi-declaration.html>. Access: Oct. 17, 2015. point 23; UNIVERSITY OF TORONTO. BRICS and Africa: partnership for development, integration and industrialization, e'Thekwini Declaration. Durban, Mar. 27, 2013. Available on: <http://www.brics.utoronto.ca/docs/130327-statement.html>. Access: Oct. 17, 2015. point 29; UNIVERSITY OF TORONTO. The 6th BRICS summit: Fortaleza Declaration. Fortaleza, July 15, 2014. Available on: <http://www.brics.utoronto.ca/docs/140715leaders.html>. Access: Oct. 17, 2015. point 42; UNIVERSITY OF TORONTO. VII BRICS summit: 2015 Ufa Declaration. Ufa, July 9, 2015. Available on: <http://www.brics.utoronto.ca/docs/150709ufa-declaration_en.html>. Access: Oct. 17, 2015. point 42. 
med by the 1948 Universal Declaration on Human Rights. Since then, the international community has been working on the establishment of an international legal and institutional human rights framework, which according to the BRICS has as its cornerstone "the principle of equitable and mutually respectful cooperation of sovereign states" $"$. Besides that, the group puts forward that in order for states to protect, respect and fulfill their human rights obligations as well as "to treat all human rights, including the right to development, in a fair and equal manner, on the same footing and with the same emphasis" ${ }^{61}$, it is necessary that the human rights agenda is not politicized. ${ }^{62}$

In the area of human rights the BRICS devotes its attention to a particular topic, namely the (right to) development that is closely connected with the group's major focus, i.e. the financial/economic architecture of the international system. In this setting, the former UN Millennium Development Goals (MDG), which were replaced by the UN Sustainable Development Goals (SDG), are perceived by the group as a fundamental milestone reached by the international society in dealing with human rights. ${ }^{63}$ According to the BRICS, these goals can only be achieved by poor and developing nations by means of cooperation (technical, economical, etc.) for the establishment of policies aiming at developing in a sustainable way their economies without disregarding groups in need of social protection, ${ }^{64}$ as put forward by MDG number 8 and SDG numbers 16

60 UNIVERSITY OF TORONTO. VII BRICS summit: $2015 \mathrm{Ufa}$ Declaration. Ufa, July 9, 2015. Available on: < http://www.brics.utoronto.ca/docs/150709-ufa-declaration_en.html>. Access: Oct. 17, 2015. point 10 .

61 UNIVERSITY OF TORONTO. The 6th BRICS summit: Fortaleza Declaration. Fortaleza, July 15, 2014. Available on: <http:// www.brics.utoronto.ca/docs/140715-leaders.html>. Access: Oct. 17, 2015. point 28 .

62 UNIVERSITY OF TORONTO. The 6th BRICS summit: Fortaleza Declaration. Fortaleza, July 15, 2014. Available on: <http:// www.brics.utoronto.ca/docs/140715-leaders.html>. Access: Oct. 17, 2015. point 28; UNIVERSITY OF TORONTO. VII BRICS summit: 2015 Ufa Declaration. Ufa, July 9, 2015. Available on: < http:// www.brics.utoronto.ca/docs/150709-ufa-declaration_en.html>. Access: Oct. 17, 2015. point 10.

63 UNIVERSITY OF TORONTO. Fourth BRICS summit: Delhi Declaration. New Delhi, Mar. 29, 2012. Available on: <http://www. brics.utoronto.ca/docs/120329-delhi-declaration.html>. Access: Oct. 17, 2015. point 35 .

64 UNIVERSITY OF TORONTO. 2nd BRIC summit of heads of state and government: joint statement. Brasília, Apr. 15, 2010. Available on: <http://www.brics.utoronto.ca/docs/100415-leaders.html>. Access: Oct. 17, 2015. point 15. and $17,{ }^{65}$ as well as by the UN Charter (Articles 1(3), 55 and 56) and other international treaties, such as the International Covenant on Economic, Social and Cultural Rights (ICESCR). Moreover according to the group, sustainable growth has to be embedded not only in the MDG/SDG framework, but also has to be entrenched in other soft law documents, such as the Agenda 21 and Rio Principles on Sustainable Development, as well as in multilateral treaties. ${ }^{66}$

Furthermore, the BRICS structures its approach towards the interconnections between the areas of human rights, environmental law and economic law on the principle of common but differentiated responsibilities, ${ }^{67}$ which was put forward in the Rio Declaration on 1992 by merging the concepts of positive discrimination from Article 2 of the International Covenant on Economic, Social and Cultural Rights (ICESCR) with the preferential treatment of developing countries present on Article XVIII of the General Agreement on Tariffs and Trade (GATT). ${ }^{68}$ The principle of common but differentiated responsibilities addresses, among other issues, the necessity for international cooperation with

65 UNIVERSITY OF TORONTO. 2nd BRIC summit of heads of state and government: joint statement. Brasília, Apr. 15, 2010. Available on: <http://www.brics.utoronto.ca/docs/100415-leaders.html>. Access: Oct. 17, 2015. point 18; eThekwini Declaration, point 38; UNIVERSITY OF TORONTO. VII BRICS summit. 2015 Ufa Declaration. Ufa, July 9, 2015. Available on: <http://www.brics.utoronto.ca/docs/150709-ufa-declaration_en.html>. Access: Oct. 17, 2015. point 66 .

66 UNIVERSITY OF TORONTO. Joint statement of the BRIC countries' leaders. Yekaterinburg, June 16, 2009. Available on: <http:// www.brics.utoronto.ca/docs/090616-leaders.html>. Access: Oct. 17, 2015. point 7; UNIVERSITY OF TORONTO. Sanya Declaration. Sanya, Apr. 14, 2011. Available on: <http://www.brics.utoronto.ca/ docs/110414-leaders.html>. Access: Oct. 17, 2015. point 23; UNIVERSITY OF TORONTO. The 6th BRICS summit: Fortaleza Declaration. Fortaleza, July 15, 2014. Available on: <http://www.brics. utoronto.ca/docs/140715-leaders.html>. Access: Oct. 17, 2015. point 54.

67 UNIVERSITY OF TORONTO. Sanya Declaration. Sanya, Apr. 14, 2011. Available on: <http://www.brics.utoronto.ca/ docs/110414-leaders.html>. Access: Oct. 17, 2015. point 23; UNIVERSITY OF TORONTO. The 6th BRICS summit: Fortaleza Declaration. Fortaleza, July 15, 2014. Available on: <http://www.brics. utoronto.ca/docs/140715-leaders.html>. Access: Oct. 17, 2015. point 54; UNIVERSITY OF TORONTO. VII BRICS summit: 2015 Ufa Declaration. Ufa, July 9, 2015. Available on: <http://www.brics. utoronto.ca/docs/150709-ufa-declaration_en.html>. Access: Oct. 17, 2015. point 66 .

68 SCHRIJVER, Nico. The evolution of sustainable development in international law: inception, meaning and status. Leiden: M. Nijhoff, 2008. p. 178-184. 
the low-income countries (LIC), ${ }^{69}$ which base their economies in the revenue of commodities. ${ }^{70}$ Consequently, the BRICS built on this principle its strategy to address its responsibility towards LIC as well as to pressure the reform of the international financial/economic architecture that currently allows "volatility in food and other commodity prices" ${ }^{\text {"11 }}$, which are harmful to developing countries.

In short, it is possible to see that the BRICS concentrate its efforts concerning human rights issues on the question of cooperation with developing states based on the MDG/SDG framework as well as on the principle of common but differentiated responsibilities. Therefore, it is likely that the BRICS-sponsored NDB will play a significant role in the group's cooperation strategy for the support of developing and LIC countries to achieve the SDG. ${ }^{72}$ This focus on the topic of development might by some be seen as a contradiction to the BRICS aim of a non-politicized human rights agen$\mathrm{da}$, as development policies are decisively defined by a political choice. However, when analyzing the BRICS approach to the right to development, it becomes clear that it is understood rather as a right owned by states, which facilitates inter-state cooperation ${ }^{73}$ and contributes to creating a more equal world order. The BRICS does thus not attach great importance to human rights

69 UNIVERSITY OF TORONTO. BRICS and Africa: partnership for development, integration and industrialization, eThekwini Declaration. Durban, Mar. 27, 2013. Available on: <http://www. brics.utoronto.ca/docs/130327-statement.html>. Access: Oct. 17, 2015. point 38. See also the International Law Association New Delhi Declaration of Principles of International Law relating to Sustainable Development, circulated as UN Doc. A/57/329 (2002). 70 UNIVERSITY OF TORONTO. BRICS and Africa: partnership for development, integration and industrialization, eThekwini Declaration. Durban, Mar. 27, 2013. Available on: <http://www. brics.utoronto.ca/docs/130327-statement.html>. Access: Oct. 17, 2015. point 38 .

71 UNIVERSITY OF TORONTO. BRICS and Africa: partnership for development, integration and industrialization, eThekwini Declaration. Durban, Mar. 27, 2013. Available on: <http://www. brics.utoronto.ca/docs/130327-statement.html>. Access: Oct. 17, 2015. point 38 .

72 UNIVERSITY OF TORONTO. The 6th BRICS summit: Fortaleza Declaration. Fortaleza, July 15, 2014. Available on: <http:// www.brics.utoronto.ca/docs/140715-leaders.html>. Access: Oct. 17, 2015. point 11.

73 UNIVERSITY OF TORONTO. The 6th BRICS summit: Fortaleza Declaration. Fortaleza, July 15, 2014. Available on: <http:// www.brics.utoronto.ca/docs/140715-leaders.html>. Access: Oct. 17, 2015. point 28; UNIVERSITY OF TORONTO. VII BRICS summit: 2015 Ufa Declaration. Ufa, July 9, 2015. Available on: <http:// www.brics.utoronto.ca/docs/150709-ufa-declaration_en.html>. Access: Oct. 17, 2015. point 10. with a particular focus on the individual as this may expose states, including its members, to criticism and thus hamper the possibilities for cooperation between states. Centering its actions on inter-state cooperation allows the BRICS to use the human rights agenda, especially the right to development, as a way to strengthen its objectives with regard to the reform of the international economic system, which is seen as a major obstacle for the realization of such right for all nations.

\subsection{International economic law}

After analyzing the areas of international peace and security as well as human rights, it becomes relevant to scrutinize the way in which the BRICS approaches themes related to the field of international economic law, due to the fact that its main area of action is in the international system's financial/economic architecture. Moreover, since the group's first summit macroeconomic issues have been at the top of the BRICS' agenda and deliberations. ${ }^{74}$ Consequently, such analysis can contribute to specify how the BRICS perspective on international law looks like. In order to present in a clear way the group's posture towards such area of international law, this part is divided into two sections, one addressing regulatory issues related to commodity prices and international trade (a), while the second section tackles the BRICS main claim, the reform of the Bretton Woods institutions (b).

a. Commodity price regulation and international trade

As mentioned before, the BRICS understands that the volatility in commodity prices is a threat to developing countries and LIC as the stability of these prices is fundamental not only for the national economy of these states, but also for a well-functioning global economy. ${ }^{75}$ Moreover, taking into account the 2008 international economic crisis and the end of the commodities' supercycle, the BRICS, as in its approach regarding the

74 KIRTON, John. BRICS evolving institutional identity: explaining the brics summit's solid strengthening success. International Organizations Research Journal, v. 10, n. 2, p. 9-31, Jun. 2015. p. 14.

75 UNIVERSITY OF TORONTO. Sanya Declaration. Sanya, Apr. 14, 2011. Available on: <http://www.brics.utoronto.ca/ docs/110414-leaders.html>. Access: Oct. 17, 2015. point 17; UNIVERSITY OF TORONTO. Fourth BRICS summit: Delhi Declaration. New Delhi, Mar. 29, 2012. Available on: <http://www.brics. utoronto.ca/docs/120329-delhi-declaration.html>. Access: Oct. 17, 2015. point 38 . 
MDG/SDG, advocates for the strengthening of international cooperation among states envisaging improving the dialogue between producers and consumers' nations as well as to support developing countries. ${ }^{76}$ As a consequence of these actions, the BRICS, from a legal point of view, puts forward the necessity to improve regulations regarding commodity prices, for example in ensuring access to "reliable and timely information on demand and supply" $" 77$ by countries in order to make international, regional and national markets more stable and less subject to recessions. ${ }^{78}$

A further element that the BRICS sees as fundamental to have a more stable market on commodities is a strong multilateral trading system coordinated and lead by the World Trade Organization (WTO) ${ }^{79}$ based on principles like inclusiveness, ${ }^{80}$ transparency, ${ }^{81}$ equal

76 UNIVERSITY OF TORONTO. 2nd BRIC summit of heads of state and government: joint statement. Brasília, Apr. 15, 2010. Available on: <http://www.brics.utoronto.ca/docs/100415-leaders.html>. Access: Oct. 17, 2015. point 13; Sanya Declaration, point 17; UNIVERSITY OF TORONTO. Fourth BRICS summit: Delhi Declaration. New Delhi, Mar. 29, 2012. Available on: <http://www.brics. utoronto.ca/docs/120329-delhi-declaration.html>. Access: Oct. 17, 2015. point 38 .

77 UNIVERSITY OF TORONTO. Sanya Declaration. Sanya, Apr. 14, 2011. Available on: <http://www.brics.utoronto.ca/ docs/110414-leaders.html>. Access: Oct. 17, 2015. point 17.

78 UNIVERSITY OF TORONTO. 2nd BRIC summit of heads of state and government: joint statement. Brasília, Apr. 15, 2010. Available on: <http://www.brics.utoronto.ca/docs/100415-leaders.html>. Access: Oct. 17, 2015. point 13; UNIVERSITY OF TORONTO. Sanya Declaration. Sanya, Apr. 14, 2011. Available on: <http://www. brics.utoronto.ca/docs/110414-leaders.html>. Access: Oct. 17, 2015. point 17; UNIVERSITY OF TORONTO. Fourth BRICS summit. Delhi Declaration. New Delhi, Mar. 29, 2012. Available on: $<$ http://www.brics.utoronto.ca/docs/120329-delhi-declaration. html>. Access: Oct. 17, 2015. point 38.

79 UNIVERSITY OF TORONTO. Joint statement of the BRIC countries' leaders. Yekaterinburg, June 16, 2009. Available on: < http:// www.brics.utoronto.ca/docs/090616-leaders.html>. Access: Oct. 17, 2015. point 5; UNIVERSITY OF TORONTO. 2nd BRIC summit of heads of state and government: joint statement. Brasília, Apr. 15, 2010. Available on: <http://www.brics.utoronto.ca/docs/100415leaders.html>. Access: Oct. 17, 2015.point 14; UNIVERSITY OF TORONTO. III BRICS summit: 2015 Ufa Declaration. Ufa, July 9, 2015. Available on: <http://www.brics.utoronto.ca/docs/150709ufa-declaration_en.html $>$. Access: Oct. 17, 2015. point 21.

80 UNIVERSITY OF TORONTO. 2nd BRIC summit of heads of state and government: joint statement. Brasília, Apr. 15, 2010. Available on: <http://www.brics.utoronto.ca/docs/100415-leaders.html>. Access: Oct. 17, 2015. point 14.

81 UNIVERSITY OF TORONTO. BRICS and Africa: partnership for development, integration and industrialization, eThekwini Declaration. Durban, Mar. 27, 2013. Available on: <http://www. brics.utoronto.ca/docs/130327-statement.html>. Access: Oct. 17, 2015. point 15 UNIVERSITY OF TORONTO. The 6th BRICS summit: Fortaleza Declaration. Fortaleza, July 15, 2014. Available on: opportunities, ${ }^{82}$ fair participation in global economy, financial and trade affairs ${ }^{83}$ and common but differentiated responsibilities. ${ }^{84}$ Consequently, international trade agreements establishing plurilateral initiatives that are not in consonance with such principles and do not seek for an inclusive and constructive outcome are disapproved by the group. ${ }^{85}$ Nevertheless, regional trade agreements that seek to make markets more open to trade and transparent in accordance with WTO rules are seen by the BRICS as an important asset to the multilateral trading system, ${ }^{86}$ where the WTO dispute settlement system is a "cornerstone of the security and predictability" 87 .

Therefore, in a nutshell, the BRICS pushes for a more inclusive international trade system based on multilateral organization, such as the WTO. Also, the group advocates for more state-made regulations aiming at bringing certainty, transparency and stability to commodity prices and to international trade. ${ }^{88}$ For example, the

<http://www.brics.utoronto.ca/docs/140715-leaders.html>. Access: Oct. 17, 2015. point 21.

82 UNIVERSITY OF TORONTO. 2nd BRIC summit of heads of state and government: joint statement. Brasília, Apr. 15, 2010. Available on: <http://www.brics.utoronto.ca/docs/100415-leaders.html>. Access: Oct. 17, 2015. point 14; UNIVERSITY OF TORONTO. The 6th BRICS summit: Fortaleza Declaration. Fortaleza, July 15, 2014. Available on: <http://www.brics.utoronto.ca/docs/140715leaders.html>. Access: Oct. 17, 2015. point 21.

83 UNIVERSITY OF TORONTO. 2nd BRIC summit of heads of state and government: joint statement. Brasília, Apr. 15, 2010. Available on: $\quad<$ http://www.brics.utoronto.ca/docs/100415-leaders.html >. Access: Oct. 17, 2015. point 14; Fortaleza Declaration, point 21.

84 UNIVERSITY OF TORONTO. BRICS and Africa: partnership for development, integration and industrialization, eThekwini Declaration. Durban, Mar. 27, 2013. Available on: <http://www. brics.utoronto.ca/docs/130327-statement.html>. Access: Oct. 17, 2015.point 15; UNIVERSITY OF TORONTO. The 6th BRICS summit: Fortaleza Declaration. Fortaleza, July 15, 2014. Available on: $<$ http://www.brics.utoronto.ca/docs/140715-leaders.html>. Access: Oct. 17, 2015. point 21.

85 UNIVERSITY OF TORONTO. Fourth BRICS summit: Delhi Declaration. New Delhi, Mar. 29, 2012. Available on: < http://www. brics.utoronto.ca/docs/120329-delhi-declaration.html>. Access: Oct. 17, 2015. point 16 .

86 UNIVERSITY OF TORONTO. The 6th BRICS summit: Fortaleza Declaration. Fortaleza, July 15, 2014. Available on: <http:// www.brics.utoronto.ca/docs/140715-leaders.html>. Access: Oct. 17, 2015. point 21; UNIVERSITY OF TORONTO. VII BRICS summit: 2015 Ufa Declaration. Ufa, July 9, 2015. Available on: <http:// www.brics.utoronto.ca/docs/150709-ufa-declaration_en.html>. Access: Oct. 17, 2015. point 21.

87 UNIVERSITY OF TORONTO. The 6th BRICS summit: Fortaleza Declaration. Fortaleza, July 15, 2014. Available on: <http:// www.brics.utoronto.ca/docs/140715-leaders.html>. Access: Oct. 17, 2015. point 21.

88 For an analysis of the interrelations between the WTO system 
(quasi) confidential negotiations of the Transatlantic Trade and Investment Partnership (TTIP) between the United States and the European Union and the Trans-Pacific Partnership (TPP) between twelve countries, from a BRICS perspective, have to be qualified as non-transparent and non-inclusive process, which might undermine the central role of the WTO as a multilateral organization responsible for managing world commerce. $^{89}$

\section{b. Reform of the Bretton Woods institutions}

According to the BRICS, the international financial architecture, established in the aftermath of the World War II by the Bretton Woods institutions, i.e. the IMF and the WB, has as its main function the establishment and maintenance of a stable, predictable and integrated international monetary system..$^{90}$ Since its creation in $2009,{ }^{11}$ the group has been defending a reform of such institutions due to the fact that the structure of these institutions does not reflect the current state of affairs of the global economy, where emergent and developing countries play a significant role. ${ }^{92}$ Not living up to this reality contributes to an increase of the legitimacy deficit of these institutions. ${ }^{93}$ As a consequence, the BRICS

and regional trade agreements, see: CAPUCIO, Camilla. WTO and regionalism in the 21st century: strategy to impose normative models? Brazilian Journal of International Law, v. 12, n. 2, p. 337-347, Aug. 2014.

89 For a deeper analysis on the impacts of the TTIP and the TPP on the WTO system, see: HAUFBAUER, Gary C.; ISAACS, Cathleen. How will TTP and TTIP Change the WTO System? Journal of International Economic Law, v. 18, n. 3, p. 679-696, Aug. 2015.

90 UNIVERSITY OF TORONTO. Joint statement of the BRIC countries' leaders. Yekaterinburg, June 16, 2009. Available on: < http:// www.brics.utoronto.ca/docs/090616-leaders.html>. Access: Oct. 17, 2015. point 3; UNIVERSITY OF TORONTO. Fourth BRICS summit: Delhi Declaration. New Delhi, Mar. 29, 2012. Available on: $<$ http://www.brics.utoronto.ca/docs/120329-delhi-declaration. html>. Access: Oct. 17, 2015. point 8; UNIVERSITY OF TORONTO. BRICS and Africa: partnership for development, integration and industrialization, eThekwini Declaration. Durban, Mar. 27, 2013. Available on: <http://www.brics.utoronto.ca/docs/130327statement.html>. Access: Oct. 17, 2015. point 13.

91 UNIVERSITY OF TORONTO. Joint statement of the BRIC countries' leaders. Yekaterinburg, June 16, 2009. Available on: < http:// www.brics.utoronto.ca/docs/090616-leaders.html>. Access: Oct. 17, 2015. point 3.

92 UNIVERSITY OF TORONTO. 2nd BRIC summit of heads of state and government: joint statement. Brasília, Apr. 15, 2010. Available on: <http://www.brics.utoronto.ca/docs/100415-leaders.html>. Access: Oct. 17, 2015 point 11.

93 UNIVERSITY OF TORONTO. Joint statement of the BRIC countries' leaders. Yekaterinburg, June 16, 2009. Available on: < http:// www.brics.utoronto.ca/docs/090616-leaders.html>. Access: Oct. 17, 2015. point 3; UNIVERSITY OF TORONTO. Sanya Declaration. has advocated for the placement of negotiations regarding global economic governance and macroeconomic policies in the G-20 that is a more inclusive and representative arena than the IMF and the WB. ${ }^{94}$

As a consequence of this plea for more inclusiveness in the international financial architecture, the BRICS puts forwards that a reform of those institutions has to be structured upon four pillars. ${ }^{95}$ The first one is democratic and transparent decision-making given the current lack of legitimacy and representation of the Bretton Woods institutions. ${ }^{96}$ The second pillar is a solid legal basis, instead of self-regulations and soft law instruments to regulate the financial market, aiming at ensuring more stability and predictability. ${ }^{97}$ The strengthening of risk management and supervisory practices as well as the coordination between national and international regulatory institutions represent the other two pillars of the groups' framework for the reform of the IMF and the WB. ${ }^{98}$

Based on these ideas, the BRICS advocates that a plan of reform of the Bretton Woods institutions "requires first and foremost a substantial shift in voting participation in decision making" 99 in order for them

Sanya, Apr. 14, 2011. Available on: <http://www.brics.utoronto.ca/ docs/110414-leaders.html>. Access: Oct. 17, 2015. point 15.

94 UNIVERSITY OF TORONTO. Sanya Declaration. Sanya, Apr. 14, 2011. Available on: <http://www.brics.utoronto.ca/ docs/110414-leaders.html>. Access: Oct. 17, 2015. point 14; UNIVERSITY OF TORONTO. Fourth BRICS summit: Delhi Declaration. New Delhi, Mar. 29, 2012. Available on: <http://www.brics. utoronto.ca/docs/120329-delhi-declaration.html>. Access: Oct. 17, 2015. point 7 .

95 UNIVERSITY OF TORONTO. Joint statement of the BRIC countries' leaders. Yekaterinburg, June 16, 2009. Available on: < http:// www.brics.utoronto.ca/docs/090616-leaders.html>. Access: Oct. 17, 2015. point 4.

96 UNIVERSITY OF TORONTO. Joint statement of the BRIC countries' leaders. Yekaterinburg, June 16, 2009. Available on: < http:// www.brics.utoronto.ca/docs/090616-leaders.html>. Access: Oct. 17, 2015. point 4; Brasília Statement, point 11.

97 UNIVERSITY OF TORONTO. Joint statement of the BRIC countries' leaders. Yekaterinburg, June 16, 2009. Available on: <http:// www.brics.utoronto.ca/docs/090616-leaders.html>. Access: Oct. 17, 2015. point 4; UNIVERSITY OF TORONTO. 2nd BRIC summit of heads of state and government: joint statement. Brasilia, Apr. 15, 2010. Available on: <http://www.brics.utoronto.ca/docs/100415-leaders. html>. Access: Oct. 17, 2015. point 13.

98 UNIVERSITY OF TORONTO. Joint statement of the BRIC countries' leaders. Yekaterinburg, June 16, 2009. Available on: <http:// www.brics.utoronto.ca/docs/090616-leaders.html>. Access: Oct. 17, 2015. point 4 .

99 UNIVERSITY OF TORONTO. 2nd BRIC summit of heads of state and government: joint statement. Brasília, Apr. 15, 2010. Available on: <http://www.brics.utoronto.ca/docs/100415-leaders.html $>$. 
to reflect the global economy scenario in a better way. According to the BRICS, this initial movement will foster transparency and allow countries that are nowadays underrepresented (e.g. emergent economies, developing and African Sub-Saharan states) to play a greater role in the IMF and the WB and make their voice heard in these forums. ${ }^{100}$ Nevertheless, it is important to mention that the BRICS proposal does not advocate for the abolishment of the quota system upon which these institutions are structured. ${ }^{101}$

So far, the reform process of the IMF and the WB has been perceived by the group as deeply disappointing ${ }^{102}$ and risking to "fade into obsolescence"103. Consequently, the BRICS sponsored the New Development Bank has to be interpreted as an institution set to complement the structures of the financial architecture, which until now could not be reformed in order to be more inclusive, democratic and representative. This means, as put forward by the group, that the NDB aims at helping emergent economies and developing countries to over-

Access: Oct. 17, 2015. point 11.

100 UNIVERSITY OF TORONTO. Joint statement of the BRIC countries' leaders. Yekaterinburg, June 16, 2009. Available on: <http:// www.brics.utoronto.ca/docs/090616-leaders.html>. Access: Oct. 17, 2015. point 3; UNIVERSITY OF TORONTO. Fourth BRICS summit: Delhi Declaration. New Delhi, Mar. 29, 2012. Available on: $<$ http://www.brics.utoronto.ca/docs/120329-delhi-declaration. html>. Access: Oct. 17, 2015. point 8; UNIVERSITY OF TORONTO. BRICS and Africa: partnership for development, integration and industrialization, eThekwini Declaration. Durban, Mar. 27, 2013. Available on: <http://www.brics.utoronto.ca/docs/130327statement.html>. Access: Oct. 17, 2015. point 13.

101 UNIVERSITY OF TORONTO. The 6th BRICS summit: Fortaleza Declaration. Fortaleza, July 15, 2014. Available on: <http:// www.brics.utoronto.ca/docs/140715-leaders.html>. Access: Oct. 17, 2015. point 18 .

102 UNIVERSITY OF TORONTO. VII BRICS summit: 2015 Ufa Declaration. Ufa, July 9, 2015. Available on: < http://www. brics.utoronto.ca/docs/150709-ufa-declaration_en.html>. Access: Oct. 17, 2015. point 19. See also: UNIVERSITY OF TORONTO. Fourth BRICS summit: Delhi Declaration. New Delhi, Mar. 29, 2012. Available on: <http://www.brics.utoronto.ca/docs/120329-delhideclaration.html>. Access: Oct. 17, 2015. point 9; UNIVERSITY OF TORONTO. BRICS and Africa: partnership for development, integration and industrialization, eThekwini Declaration. Durban, Mar. 27, 2013. Available on: <http://www.brics.utoronto.ca/ docs/130327-statement.html>. Access: Oct. 17, 2015. point 13; UNIVERSITY OF TORONTO. The 6th BRICS summit: Fortaleza Declaration. Fortaleza, July 15, 2014. Available on: <http://www. brics.utoronto.ca/docs/140715-leaders.html>. Access: Oct. 17, 2015. point 18 .

103 UNIVERSITY OF TORONTO. 2nd BRIC summit of heads of state and government: joint statement. Brasília, Apr. 15, 2010. Available on: <http://www.brics.utoronto.ca/docs/100415-leaders.html>. Access: Oct. 17, 2015. point 11. come the constraints imposed by the current international financial architecture that block the realization of investments in the area of infrastructure necessary to achieve a sustainable pattern of development. ${ }^{104}$

\section{THE STRUCTURE OF THE BRICS PERSPECTIVE ON INTERNATIONAL LAW}

After analyzing how the BRICS perceives and deals with different fields of international law, this section identifies the structures of the BRICS perspective on international law. It is divided into three parts aiming at covering, from a BRICS point of view, the international legalization process as well as the role of states, international organizations and individuals in international law.

\subsection{International law as the product of multila- teral and non-confrontational consensus buil- ding}

The reading of the BRICS documents through the lenses of international peace and security, human rights and international economic law appoints to a framework upon which the BRICS perspective on international law is structured. The first characteristic of this approach is the reliance by the BRICS on multilateral international organizations, such as the UN and the WTO. According to the group, these organizations that allow states to undertake multilateral negotiations on global problems with actors from different backgrounds should have a central place in the global governance structure. ${ }^{105}$

104 UNIVERSITY OF TORONTO. The 6th BRICS summit: Fortaleza Declaration. Fortaleza, July 15, 2014. Available on: <http:// www.brics.utoronto.ca/docs/140715-leaders.html>. Access: Oct. 17, 2015. point 11 .

105 UNIVERSITY OF TORONTO. Sanya Declaration. Sanya, Apr. 14, 2011. Available on: <http://www.brics.utoronto.ca/ docs/110414-leaders.html>. Access: Oct. 17, 2015. point 8; UNIVERSITY OF TORONTO. Fourth BRICS summit: Delhi Declaration. New Delhi, Mar. 29, 2012. Available on: <http://www.brics. utoronto.ca/docs/120329-delhi-declaration.html>. Access: Oct. 17, 2015. point 7; UNIVERSITY OF TORONTO. BRICS and Africa: partnership for development, integration and industrialization, eThekwini Declaration. Durban, Mar. 27, 2013. Available on: <http://www.brics.utoronto.ca/docs/130327-statement.html>. Access: Oct. 17, 2015. point 20; UNIVERSITY OF TORONTO. The 6th BRICS summit: Fortaleza Declaration. Fortaleza, July 15, 2014. Available on: <http://www.brics.utoronto.ca/docs/140715leaders.html>. Access: Oct. 17, 2015. points 5, 10, 25. 
From a BRICS perspective on international law, the reasons why decisions should be adopted in multilateral settings is related to the fact that they are more inclusive and democratic institutions in which developing countries have more space for action than in other organizations that currently suffer from a legitimacy deficit, such as the IMF. ${ }^{106}$ The roots of such plea can be found in the Declaration on the Establishment of a New International Economic Order, which already in the 1970's proposed a "full and effective participation on the basis of equality of all countries in the solving of world economic problems in the common interest of all"107. Moreover, this understanding was shared by the Report of the Commission of Experts of the President of the United Nations General Assembly on Reforms of the International Monetary and Financial System presented in the year of the first BRICS Summit, which attested the non-democratic nature of the global financial/economic architecture, especially the IMF and the WB, and proposed to give "a greater voice for developing countries" 108 , something that is possible in multilateral organizations, such as the UN and the WTO.

In this search for the achievement of a common ground among the different players, which might take conflicting positions in multilateral settings, a BRICS perspective suggests the use of a non-confrontational approach based on consensus and open to all the members of the international community without any kind of distinction. ${ }^{109}$ This means,

106 UNIVERSITY OF TORONTO. 2nd BRIC summit of heads of state and government: joint statement. Brasília, Apr. 15, 2010. Available on: <http://www.brics.utoronto.ca/docs/100415-leaders.html>. Access: Oct. 17, 2015. point 11; UNIVERSITY OF TORONTO. Fourth BRICS summit: Delhi Declaration. New Delhi, Mar. 29, 2012. Available on: <http://www.brics.utoronto.ca/docs/120329-delhideclaration.html>. Access: Oct. 17, 2015. point 9; UNIVERSITY OF TORONTO. BRICS and Africa: partnership for development, integration and industrialization, eThekwini Declaration. Durban, Mar. 27, 2013. Available on: <http://www.brics.utoronto.ca/ docs/130327-statement.html>. Access: Oct. 17, 2015. point 18; UNIVERSITY OF TORONTO. VII BRICS summit: 2015 Ufa Declaration. Ufa, July 9, 2015. Available on: <http://www.brics.utoronto.ca/docs/150709-ufa-declaration_en.html>. Access: Oct. 17, 2015.point 18 .

107 UNITED NATIONS. General Assembly. Declaration on the establishment of a new international economic order. New York: UN, May 1974 Available in: <http://www.un-documents.net/s6r3201.htm>. Access: Fev. 05, 2016. para. 4 (c).

108 UNITED NATIONS. General Assembly. Report of the commission of experts of the president of the United Nations General Assembly on reforms of the international monetary and financial system. New York: UN, 21 Sept. 2009. Available on: <http://www.un.org/ga/econcrisissummit/docs/FinalReport_CoE.pdf>. Access: 17 Oct. 2015.

109 UNIVERSITY OF TORONTO. Sanya Declaration. Sanya, if the adoption of a decision might raise a conflict among the participants, it is preferable not to approve it. Consequently, it is possible to identify the role played by several principles such as horizontality, pragmatism and collective decision-making underlined by such non-confrontational approach, i.e. unanimous decisions, which also guide the BRICS countries when they are deliberating within the group. ${ }^{110}$

For instance, one of the most sensible topics within the BRICS, the reform of the UN system, shows the importance and respect of the non-confrontational approach within the group. When the wide-open and expressive support given by the group to the admission of Russia as a member of the World Trade Organization ${ }^{111}$ is compared with the encouragement regarding the reform of the UN, particularly the Security Council, it is rather modest and cannot be explicitly found in any of the BRICS declarations. Until now, the BRICS just agreed to support the aspirations of Brazil, India and South Africa "to play a greater role" in the organization. ${ }^{112}$ Thus, these countries defending the reform of

Apr. 14, 2011. Available on: <http://www.brics.utoronto.ca/ docs/110414-leaders.html>. Access: Oct. 17, 2015. point 6.

110 UNIVERSITY OF TORONTO. Sanya Declaration. Sanya, Apr. 14, 2011. Available on: <http://www.brics.utoronto.ca/ docs/110414-leaders.html>. Access: Oct. 17, 2015. point 6.

111 UNIVERSITY OF TORONTO. 2nd BRIC summit of heads of state and government: joint statement. Brasília, Apr. 15, 2010. Available on: <http://www.brics.utoronto.ca/docs/100415-leaders.html>. Access: Oct. 17, 2015. point 14; UNIVERSITY OF TORONTO. Sanya Declaration. Sanya, Apr. 14, 2011. Available on: < http://www. brics.utoronto.ca/docs/110414-leaders.html>. Access: Oct. 17, 2015. point 26; UNIVERSITY OF TORONTO. Fourth BRICS summit: Delhi Declaration. New Delhi, Mar. 29, 2012. Available on: $<$ http://www.brics.utoronto.ca/docs/120329-delhi-declaration. html>. Access: Oct. 17, 2015. point 15. The Russian Federation is a WTO member since 2012.

112 UNIVERSITY OF TORONTO. Joint statement of the BRIC countries' leaders. Yekaterinburg, June 16, 2009. Available on: < http:// www.brics.utoronto.ca/docs/090616-leaders.html>. Access: Oct. 17, 2015. point 14; UNIVERSITY OF TORONTO. 2nd BRIC summit of heads of state and government: joint statement. Brasília, Apr. 15, 2010. Available on: <http://www.brics.utoronto.ca/docs/100415leaders.html>. Access: Oct. 17, 2015. point 4; UNIVERSITY OF TORONTO. Sanya Declaration. Sanya, Apr. 14, 2011. Available on: $<$ http://www.brics.utoronto.ca/docs/110414-leaders.html>. Access: Oct. 17, 2015. point 8; UNIVERSITY OF TORONTO. Fourth BRICS summit: Delhi Declaration. New Delhi, Mar. 29, 2012. Available on: <http://www.brics.utoronto.ca/docs/120329-delhideclaration.html>. Access: Oct. 17, 2015. point 26; UNIVERSITY OF TORONTO. BRICS and Africa: partnership for development, integration and industrialization, eThekwini Declaration. Durban, Mar. 27, 2013. Available on: <http://www.brics.utoronto.ca/ docs/130327-statement.html>. Access: Oct. 17, 2015. point10; UNIVERSITY OF TORONTO. The 6th BRICS summit: Fortaleza 
the Security Council aiming at making it more culturally and geographically representative are looking for other forums to discuss this topic, for example, the Group of Four (G-4), which is formed by Brazil, Germany, India and Japan.

Hence, it can be put forward that the harmony and common understanding among state actors about international law as well as "the need for universal adherence to principles and rules of international law in their interrelation and integrity, discarding the resort to 'double standards' and avoiding placing interests of some countries above others" ${ }^{\prime 13}$ represents the basis of the BRICS perspective on international law. Departing from this baseline, the BRICS approaches questions related to the issues of legal bindingness and precision, which can be perceived in the way that the group relates to the fields of international economic law (pleas for more specific regulations) and international peace and security (reliance on general principles of international law).

\subsection{Legal bindingness and precision as a conse- quence of a multilateral consensus building}

When approaching the area of international economic law, the BRICS advocates for more international regulations based on a determined set of underlying principles in order to replace soft law agreements or self-regulatory initiatives aiming at achieving more certainty, predictability and stability in the system. ${ }^{114}$ However, the same reasoning does not hold true when consensus is not present within the BRICS, as in the case of questions regarding international peace and security. As a consequence, the BRICS perspective pushes for a

Declaration. Fortaleza, July 15, 2014. Available on: <http://www. brics.utoronto.ca/docs/140715-leaders.html>. Access: Oct. 17, 2015. point 25 .

113 UNIVERSITY OF TORONTO. VII BRICS summit: 2015 Ufa Declaration. Ufa, July 9, 2015. Available on: <http://www.brics. utoronto.ca/docs/150709-ufa-declaration_en.html>. Access: Oct. 17, 2015. point 6 .

114 UNIVERSITY OF TORONTO. Joint statement of the BRIC countries' leaders. Yekaterinburg, June 16, 2009. Available on: <http:// www.brics.utoronto.ca/docs/090616-leaders.html>. Access: Oct. 17, 2015. point 3; UNIVERSITY OF TORONTO. Fourth BRICS summit: Delhi Declaration. New Delhi, Mar. 29, 2012. Available on: <http://www.brics.utoronto.ca/docs/120329-delhi-declaration. html>. Access: Oct. 17, 2015. point 8; UNIVERSITY OF TORONTO. BRICS and Africa: partnership for development, integration and industrialization, eThekwini Declaration. Durban, Mar. 27, 2013. Available on: <http://www.brics.utoronto.ca/docs/130327statement.html>. Access: Oct. 17, 2015. point 13. more flexible and vague approach towards international law by referring to concepts such as general principles of international law that allow a greater room for maneuver to states to use diplomatic arrangements. ${ }^{115}$

Yet, the BRICS approach to the international legalization cannot be understood through the binary division between hard/specific vs. soft/vague international law, as the group's perspective on international law and issues regarding normativity, especially the degrees of legal bindingness and precision are a "question of more or less". ${ }^{116}$ This means, according to a BRICS perspective the process of legalization is determined by the relations between international politics and international law, in the sense that the first limits the second's autonomy, while the latter gives sense to the former. ${ }^{117}$ Consequently, it is during the consensus-building process, which is embedded in the field of international politics, where different players by engaging themselves in a common discursive setting end-up by shaping the normative outcome, i.e. the levels of bindingness (hard or soft) and precision of the norm aiming at giving sense and legitimacy to their actions. ${ }^{118}$ Nevertheless, it is important to detach the notions of bindingness and precision. Although it is possible to perceive in the BRICS

115 UNIVERSITY OF TORONTO. Joint statement of the BRIC countries' leaders. Yekaterinburg, June 16, 2009. Available on: < http:// www.brics.utoronto.ca/docs/090616-leaders.html>. Access: Oct. 17, 2015. point 12; UNIVERSITY OF TORONTO. 2nd BRIC summit of heads of state and government: joint statement. Brasília, Apr. 15, 2010. Available on: <http://www.brics.utoronto.ca/docs/100415leaders.html>. Access: Oct. 17, 2015. point 2; UNIVERSITY OF TORONTO. Sanya Declaration. Sanya, Apr. 14, 2011. Available on: $<$ http://www.brics.utoronto.ca/docs/110414-leaders.html>. Access: Oct. 17, 2015. points 7, 11; UNIVERSITY OF TORONTO. Fourth BRICS summit: Delhi Declaration. New Delhi, Mar. 29, 2012. Available on: <http://www.brics.utoronto.ca/docs/120329-delhideclaration.html>. Access: Oct. 17, 2015. points 4, 25; UNIVERSITY OF TORONTO. BRICS and Africa: Partnership for development, integration and industrialization, eThekwini Declaration. Durban, Mar. 27, 2013. Available on: <http://www.brics.utoronto. ca/docs/130327-statement.html>. Access: Oct. 17, 2015. points 1, 21; UNIVERSITY OF TORONTO. The 6th BRICS summit: Fortaleza Declaration. Fortaleza, July 15, 2014. Available on: <http:// www.brics.utoronto.ca/docs/140715-leaders.html>. Access: Oct. 17, 2015. points 2, 27.

116 WEIL, Prosper. Towards relative normativity in international law? The American Journal of International Law, v. 77, n. 3, p. 413-442, Jul. 1983. p. 421.

117 ABBOT, Kenneth; SINDAL, Duncan. Hard and soft law in international governance. International Organization, v. 53, n. 3, p. 421453, Jun. 2000. p. 455.

118 RISSE, Thomas; ROPP, Stephen; SIKKINK, Kathrin. The persistent power of human rights: from commitment to compliance. Cambridge: Cambridge University, 2013. p. 6. 
practice the use of vague expressions, such as general principles of international law, this does not mean that these terms have a low level of bindingness, as is the case with the principle of self-determination, which is a general principle of international law with an erga omnes character. ${ }^{119}$

Consequently, it can be noticed that the BRICS perspective on international law reflects the group's consensus building process, which is centered on the non-confrontational character aiming at granting plenty of space for the states involved. Therefore, it is possible to affirm that the levels of legal precision, which might be seen as constraints of states' actions, are intrinsically related to the degree of consensus among the participants.

\subsection{The State as the measure of all things}

Another characteristic of the BRICS perspective on international law, even though recognizing the importance of multilateral organization, ${ }^{120}$ is the preference for a Westphalian approach, ${ }^{121}$ which centers all the debates and actions regarding the discipline in one of its players, the state, and in the ideas correlated to it, such as sovereignty, states' equality and non-intervention. ${ }^{122}$

119 East Timor (Portugal v. Australia), Judgment, I. C. J. Reports 1995, p. 90. para. 29. See also: Legal Consequences of the Construction of a Wall in the Occupied Palestinian Territory, Advisory Opinion, I. C. J. Reports 2004, p. 136. para. 87.

120 UNIVERSITY OF TORONTO. Sanya Declaration. Sanya, Apr. 14, 2011. Available on: <http://www.brics.utoronto.ca/ docs/110414-leaders.html>. Access: Oct. 17, 2015. point 8; UNIVERSITY OF TORONTO. Fourth BRICS summit: Delhi Declaration. New Delhi, Mar. 29, 2012. Available on: <http://www.brics. utoronto.ca/docs/120329-delhi-declaration.html>. Access: Oct. 17, 2015. point 7; UNIVERSITY OF TORONTO. BRICS and Africa: partnership for development, integration and industrialization, eThekwini Declaration. Durban, Mar. 27, 2013. Available on: <http://www.brics.utoronto.ca/docs/130327-statement.html>. Access: Oct. 17, 2015. point 20; UNIVERSITY OF TORONTO. The 6th BRICS summit: Fortaleza Declaration. Fortaleza, July 15, 2014. Available on: <http://www.brics.utoronto.ca/docs/140715leaders.html>. Access: Oct. 17, 2015. points 5, 10, 25.

121 GROTE, Rainer. Westphalian System. Max Planck Encyclopedia of Public International Law. Oxford: Oxford University, 2006.

122 UNIVERSITY OF TORONTO. Fourth BRICS summit: Delhi Declaration. New Delhi, Mar. 29, 2012. Available on: <http://www. brics.utoronto.ca/docs/120329-delhi-declaration.html>. Access: Oct. 17, 2015. point 21; UNIVERSITY OF TORONTO. BRICS and Africa: partnership for development, integration and industrialization, eThekwini Declaration. Durban, Mar. 27, 2013. Available on: <http://www.brics.utoronto.ca/docs/130327-statement.html>. Access: Oct. 17, 2015. point 26; UNIVERSITY OF TORONTO.
Consequently, the international arena, in the group's view, should be a space where its main actors, the states, can have plenty of space and few limits to implement their maneuvers. Therefore, states' interests, which are shaped through the consensus-building process via international politics, play a determining role in limiting the functions of multilateral organizations.

The importance of international law as a shaping factor of states' interests in such context has already been put forward by Virally. ${ }^{123}$ According to him, the manifestations of states' sovereignty in the domain of international organizations are a decisive factor in defining not only the functional limits, but also the practice of these institutions. ${ }^{124}$ This idea can be perceived in the BRICS perspective on international law, when the group puts forward its views and proposals regarding the reform of the Bretton Woods institutions, tackling not only their structure and aiming at granting more representation to emergent economies and developing countries, ${ }^{125}$ but also their practices, such as in the selection process of their heads and executives. ${ }^{126}$

Besides, it is also important to mention that individuals do not play a relevant role in the BRICS perspective on international law, even though their protection via the framework of international human rights law is one of the pillars of the international legal system. ${ }^{127}$ Moreover, according to the group's perspective, the international human rights framework has to be seen through the lenses of "the

The 6th BRICS summit: Fortaleza Declaration. Fortaleza, July 15, 2014. Available on: <http://www.brics.utoronto.ca/docs/140715leaders.html>. Access: Oct. 17, 2015. point 37.

123 VIRALLY, Michel. La notion de fonction dans la théorie de l'organisation internationale. In: ___. Le droit international en devenir: essais écrits au fil des ans. Paris: Universitaires de France, 1990. p. $277-300$.

124 VIRALLY, Michel. La notion de fonction dans la théorie de l'organisation internationale. In: ___. Le droit international en devenir: essais écrits au fil des ans. Paris: Universitaires de France, 1990. p. 277-300. See also: SCHERMERS, Henry G.; BLOKKER, Niels M. International institutional law. Leiden: M. Nijhoff, 2011. p. 17-22.

125 See, for example: UNIVERSITY OF TORONTO. The 6 th BRICS summit: Fortaleza Declaration. Fortaleza, July 15, 2014. Available on: <http://www.brics.utoronto.ca/docs/140715-leaders. html>. Access: Oct. 17, 2015. point 18.

126 UNIVERSITY OF TORONTO. Joint statement of the BRIC countries' leaders. Yekaterinburg, June 16, 2009. Available on: <http:// www.brics.utoronto.ca/docs/090616-leaders.html>. Access: Oct. 17, 2015. point 3.

127 UN Charter, Articles 1 and 55. See also: MERON, Theodor. International law in the age of human rights: general Course on public international law. Leiden: Hague Academy of International Law, 2004. p. $9-403$. 
principle of equitable and mutually respectful cooperation of sovereign states" ${ }^{\prime 28}$, which contrasts with the idea established at the international level that such rights "are not a web of inter-State exchanges of mutual obligations, [but]

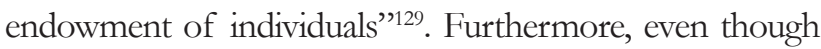
recognizing the interconnection and interdependence of all human rights, ${ }^{130}$ the BRICS mainly focus its attentions on the right to development, which in its perspective can be understood more as a right owned by states rather than by individuals as put forward by the UN Declaration on the Right to Development.

Moreover, from the BRICS Summits' documents it is possible to perceive that in the few mentions in which the group deals with individuals living on their territories, it bases its approach on the concept of people-to-people contact (or connectivity). ${ }^{131}$ This expression is restrictively used to express the group's aim to foster the cooperation within itself in the areas of education and culture. In order to bolster the people-to-people connectivity, the group has signed during the Ufa Summit an international treaty that has as one of its goals to facilitate the rapprochement of BRICS' peoples via inter-state cooperation. ${ }^{132}$

Therefore, it is possible to affirm that a BRICS perspective on international law is structured and shaped

128 UNIVERSITY OF TORONTO. VII BRICS summit: 2015 Ufa Declaration. Ufa, July 9, 2015. Available on: <http:/ /www.brics. utoronto.ca/docs/150709-ufa-declaration_en.html>. Access: Oct. 17, 2015. point 10 .

129 UNITED NATIONS. Human Rights Committee, General Comment 24 (52), General comment on issues relating to reservations made upon ratification or accession to the Covenant or the Optional Protocols thereto, or in relation to declarations under article 41 of the Covenant, U.N. Doc. CCPR/C/21/Rev.1/Add.6 (1994). Minneapolis: University of Minnesota, 2004. Available in: <https://www1.umn.edu/humants/ gencomm/hrcom24.htm>. Access: Fev. 05, 2016 para. 17.

130 UNIVERSITY OF TORONTO. The 6 th BRICS summit: Fortaleza Declaration. Fortaleza, July 15, 2014. Available on: <http:// www.brics.utoronto.ca/docs/140715-leaders.html>. Access: Oct. 17, 2015. point 28.

131 UNIVERSITY OF TORONTO. Fourth BRICS summit: Delhi Declaration. New Delhi, Mar. 29, 2012. Available on: <http:// www.brics.utoronto.ca/docs/120329-delhi-declaration.html>. Access: Oct. 17, 2015. point 40; UNIVERSITY OF TORONTO. The 6th BRICS summit: Fortaleza Declaration. Fortaleza, July 15, 2014. Available on: <http://www.brics.utoronto.ca/docs/140715-leaders. html>. Access: Oct. 17, 2015. point 56; UNIVERSITY OF TORONTO. VII BRICS summit: 2015 Ufa Declaration. Ufa, July 9, 2015. Available on: <http://www.brics.utoronto.ca/docs/150709ufa-declaration_en.html >. Access: Oct. 17, 2015. point 56.

132 UNIVERSITY OF TORONTO. Agreement between the governments of the BRICS states on cooperation in the field of culture. Ufassia, July 9, 2015. Available on: <http://www.brics.utoronto.ca/ docs/150709-culture-agreement-en.html>. Access: Oct. 17, 2015. by the continuous interactions between the fields of international relations, represented by the consensus-building process, and international law, which is used to give form to the commitments. Moreover, the idea of state sovereignty with all its manifestations, such as the notions of non-intervention and horizontality in states' relations, play a significant role for the group's perspective. As a consequence, the BRICS approaches towards different areas of international law vary in accordance with the consensus-building processes in multilateral organizations, but always share as a "lowest common denominator" a state-centrist character.

\section{Final considerations}

Nowadays the BRICS are a key-actor in the international scenario and the levels of cooperation and institutionalization within the group are increasing each year. Therefore, this paper had as its goals to identify whether there is a BRICS perspective on international law and how it is structured. After all, it is possible to conclude that there is a BRICS' perspective on international law.

As a product of its time, which is still in its very early stages, the BRICS can be seen as an actor embodied with the aim to change the world order, which uses international law either as a way to legitimize its discourse when pleading for a more inclusive international financial/economic architecture or to consolidate its achievements, as in the case of the agreement establishing the NDB. Moreover, the BRICS prioritize an international law that can be seen as the outcome of the consensus-building process held at multilateral organizations, which at the same time grants plenty of space for states to participate as well as to make their objections. Therefore, the BRICS perspective relies on a strong state-centrist approach towards the most different areas of international law, including the ones commonly characterized as centered in the individual, such as the field of human rights.

\section{References}

ABBOT, Kenneth; SINDAL, Duncan. Hard and soft law in international governance. International Organization, v. 53, n. 3, p. 421-453, Jun. 2000. 
BRAGA, Erika. Um panorama sobre as negociações do Pacote de Bali e os seus desdobramentos no âmbito da OMC. Brazilian Journal of International Law. v. 12, n. 2, p. 16-20, dez. 2014.

CAPUCIO, Camilla. WTO and regionalism in the 21 st century: strategy to impose normative models? Brazilian Journal of International Law, v. 12, n. 2, p. 337-347, Aug. 2014.

COOPER, Andrew; FAROOQ, Assif. Testing the club dynamics of the BRICS: the new development bank from conception to establishment. International Organizations Research Journal, v. 10, n. 2, p. 32-44, Jun. 2015.

FERDINAND, Peter. Rising powers at the UN: an analysis of the voting behaviour of BRICS in the General Assembly. Third World Quarterly, v. 35, n. 3, p. 376391, May 2014.

GROTE, Rainer. Westphalian System. Max Planck Encyclopedia of Public International Law. Oxford: Oxford University, 2006.

GUGGENHEIM, Paul. Traité de droit international. Genève: Libraire Georg, 1967.

HAUFBAUER, Gary C.; ISAACS, Cathleen. How will TTP and TTIP Change the WTO System? Journal of International Economic Law, v. 18, n. 3, p. 679-696, Aug. 2015.

KEUKELEIRE, Stephan et al. The EU Foreign Policy towards the BRICS and other emerging powers: objectives and strategies. Brussels: European Parliament, Oct. 2009. Available on: <https://www.google.com.br/url?sa=t\& $\mathrm{rct}=\mathrm{j} \& \mathrm{q}=\&$ esrc $=\mathrm{s} \&$ source $=$ web\&cd $=1 \& \mathrm{cad}=\mathrm{rja} \& u a c$ $\mathrm{t}=8 \& v e d=0$ ahUKEwi4mcvBtuDKAhXIgZAKHfztA EIQFggfMAA\&url=http $\% 3 \mathrm{~A} \% 2 \mathrm{~F} \% 2 \mathrm{Fwww}$.europarl. europa.eu $\% 2 \mathrm{Fcommittees} \% 2 \mathrm{Fen} \% 2 \mathrm{~F}$ studiesdownlo ad.html\%3FlanguageDocument $\% 3$ DEN $\% 26$ file $\% 3 \mathrm{D} 4$ 9151\&usg=AFQjCNG5J6ipEQ5iXvDSwbAi01VZhes bPQ\&sig2=NWyUUYcBlZeATEH_ed07PA>. Access: Oct. 16, 2015.

KIRSCH, Philippe; HOLMES, John T. The Rome Conference on an International Criminal Court: The Negotiating Process. The American Journal of International Law, v. 93, n. 1, p. 2-12, Jan. 1999.

KIRTON, John. BRICS evolving institutional identity: explaining the BRICS summit's solid strengthening success. International Organizations Research Journal, v. 10, n. 2, p. 9-31, Jun. 2015.
KOSKENNIEMI, Martti; LEINO, Päivi. Fragmentation of international law? postmodern anxieties. Leiden Journal of International Law, v. 15, n. 3, p. 553-579, Sept. 2002.

KUOVO, Sari; PEARSON, Zoe (Ed.). Feminist perspectives on contemporary international law: between resistance and compliance? Oxford: Hart, 2011.

MERON, Theodor. International law in the age of buman rights: general Course on public international law. Leiden: Hague Academy of International Law, 2004.

MUTUA, Makau. What it TWAIL? In: ANNUAL MEETING AMERICAN SOCIETY OF INTERNATIONAL LAW, 94., Washington, 2000. Proceedings...Washington: ASIL, Apr. 2000. p. 31-39.

NEHAMAS, Alexander. Nietæsche: life as literature. Cambridge: Harvard University, 1985.

NIETZSCHE, Friedrich. The will to power. New York: Vintage Books, 1967.

O’NEILL, Jim. Building better global economic BRICs. New York: Goldman, Sach, Nov. 2001. (Global Economics Paper, n. 66). Available on: <http://www.goldmansachs.com/our-thinking/archive/archive-pdfs/build-better-brics.pdf>. Access: Oct. 16, 2015.

PAUWELYN, Joost. Informal international lawmaking: framing the concept and research questions. In: PAUWELYN, Joost; WESSEL, Ramses; WOUTERS, Jan (Ed.). Informal international lawmaking. Oxford: Oxford University, 2012. p. 13-34.

REIS, Maria E. F. BRICS: genesis and evolution. In: PIMENTEL, José Vicente de Sá (Ed.). Brazil, BRICS and the international agenda. Brasília: FUNAG, 2013. p. 47-71.

REWIZORSKI, Marek (Ed.). The European Union and the BRICS: complex relations in the Era of Global Governance. New York: Springer, 2015.

RISSE, Thomas; ROPP, Stephen; SIKKINK, Kathrin. The persistent power of human rights: from commitment to compliance. Cambridge: Cambridge University, 2013.

RUSSIA. Presidency. Official Website of Russia's Presidency in BRICS:BRICS in numbers. 2015. Available on: < http:/ / en.brics2015.ru/infographics/20150301/24260.html>. Access: Oct. 16, 2015.

SALMON, Trevor. The nature of peace and security. In: MATHER, Alexander; BRYDEN, John (Ed.). Encyclopedia of life support systems, regional sustainable development. 
Paris: UNESCO, 2009. p. 259-276.

SCHERMERS, Henry G.; BLOKKER, Niels M. International institutional law. Leiden: M. Nijhoff, 2011.

SCHRIJVER, Nico. The evolution of sustainable development in international law: inception, meaning and status. Leiden: M. Nijhoff, 2008.

SCHUTTER, Olivier de. International human rights law: cases, materials and commentary. Cambridge: Cambridge University, 2010.

SHAW, Malcolm. International law. Cambridge: Cambridge University, 2008.

TALMON, Stefan. The security council as world legislature. The American Journal of International Law, v. 99, n. 1, p. 175-193, Jan. 2005.

TSINGOU, Eleni. Club governance and the making of global financial rules. Review of International Political Economy, v. 22, n. 2, p. 225-256, Mar. 2015.

UNITED NATIONS. General Assembly. Report of the commission of experts of the president of the United Nations General Assembly on reforms of the international monetary and financial system. New York: UN, 21 Sept. 2009. Available on: <http://www.un.org/ga/econcrisissummit/docs/ FinalReport_CoE.pdf>. Access: 17 Oct. 2015.

UNITED NATIONS. General Assembly. Declaration on the establishment of a new international economic order. New York: UN, May 1974. Available in: <http://www.undocuments.net/s6r3201.htm>. Access: Fev. 05, 2016.

UNITED NATIONS. Human Rights Committee, General Comment 24 (52), General comment on issues relating to reservations made upon ratification or accession to the Covenant or the Optional Protocols thereto, or in relation to declarations under article 41 of the Covenant, U.N. Doc. CCPR/C/21/Rev.1/Add.6 (1994). Minneapolis: University of Minnesota, 2004. Available in: <https:// www1.umn.edu/humanrts/gencomm/hrcom24.htm>. Access: Fev. 05, 2016.

UNIVERSITY OF TORONTO. 2nd BRIC summit of heads of state and government: joint statement. Brasília, Apr. 15, 2010. Available on: <http:/ /www.brics.utoronto.ca/ docs/100415-leaders.html>. Access: Oct. 17, 2015.

UNIVERSITY OF TORONTO. Agreement between the governments of the BRICS states on cooperation in the field of culture. Ufassia, July 9, 2015. Available on: <http://www. brics.utoronto.ca/docs/150709-culture-agreement-en. html>. Access: Oct. 17, 2015.
UNIVERSITY OF TORONTO. Agreement on the New Development Bank. Fortaleza, July 15, 2014. Available on: $<$ http://www.brics.utoronto.ca/docs/140715-bank. html>. Access: Oct. 17, 2015.

UNIVERSITY OF TORONTO. BRICS and Africa: partnership for development, integration and industrialization, eThekwini Declaration. Durban, Mar. 27, 2013. Available on: <http://www.brics.utoronto.ca/ docs/130327-statement.html>. Access: Oct. 17, 2015.

UNIVERSITY OF TORONTO. Fourth BRICS summit: Delhi Declaration. New Delhi, Mar. 29, 2012. Available on: <http://www.brics.utoronto.ca/docs/120329-delhi-declaration.html>. Access: Oct. 17, 2015.

UNIVERSITY OF TORONTO. Joint statement of the BRIC countries' leaders. Yekaterinburg, June 16, 2009. Available on: <http://www.brics.utoronto.ca/ docs/090616-leaders.html>. Access: Oct. 17, 2015.

UNIVERSITY OF TORONTO. Memorandum of understanding on the creation of the joint BRICS Website. Ufa, July 9, 2015. Available on: <http://www.brics.utoronto.ca/ docs/150709-website-en.html> Access: Oct. 17, 2015.

UNIVERSITY OF TORONTO. Sanya Declaration. Sanya, Apr. 14, 2011. Available on: <http://www.brics.utoronto.ca/docs/110414-leaders.html>. Access: Oct. 17, 2015.

UNIVERSITY OF TORONTO. The 6th BRICS summit: Fortaleza Declaration. Fortaleza, July 15, 2014. Available on: <http://www.brics.utoronto.ca/docs/140715leaders.html>. Access: Oct. 17, 2015.

UNIVERSITY OF TORONTO. VII BRICS summit: 2015 Ufa Declaration. Ufa, July 9, 2015. Available on: $<$ http://www.brics.utoronto.ca/docs/150709-ufa-declaration_en.html>. Access: Oct. 17, 2015.

VIRALLY, Michel. La notion de fonction dans la théorie de l'organisation internationale. In: __. Le droit international en devenir: Essais écrits au fil des ans. Paris: Universitaires de France, 1990. p. 277-300.

WEIL, Prosper. Towards relative normativity in international law? The American Journal of International Law, v. 77, n. 3, p. 413-442, Jul. 1983.

WTO MINISTERIAL CONFERENCE, 9., 2013, Bali, 2013. Proceedings... Valencia: Instituto de Tecnología y Alimentos Agroquímica, 2014. Available at: <https:// www.wto.org/english/thewto_e/minist_e/mc9_e/ balipackage_e.htm> Access: 21 Oct. 2015. 
Para publicar na Revista de Direito Internacional, acesse o endereço eletrônico www.rdi.uniceub.br ou www.brazilianjournal.org.

Observe as normas de publicação, para facilitar e agilizar o trabalho de edição. 